\title{
DE LA SITUACIÓN PATRIMONIAL DE LAS UNIONES DE HECHO EN EL ORDENAMIENTO JURÍDICO ESPAÑOL*
}

\author{
ASSET-RELATED MATTERS OF UNREGISTERED PARTNERSHIPS
}

IN THE SPANISH LEGAL SYSTEM

DE LA SITUATION FINANCIÈRE DES UNIONS DE FAIT DANS

LE SYSTÈME JURIDIQUE ESPAGNOL

DaVid VArgas Aravena**

\begin{abstract}
RESUMEN
La ruptura de los convivientes puede plantear diversas reclamaciones, que pueden ser por la liquidación del régimen de bienes existentes entre ellos, o por las pretensiones compensatorias por la prestación de servicios realizados por uno en beneficio del otro durante la convivencia. En este trabajo se analizan las diversas soluciones que la doctrina y la jurisprudencia española han desarrollado, frente a la multiplicidad de problemas por la falta de regulación estatal en la disolución de las uniones de hecho, aspiración que también es compartida por las crecientes leyes autonómicas y forales.
\end{abstract}

PALABRAS CLAVE: Uniones de hecho - Convivencia more uxorio - Disolución uniones de hecho - Consecuencias patrimoniales

\section{ABSTRACT}

A broken partnership may be surrounded by several complaints by the former partners. They could be caused by the liquidation or final settlement of the goods and values acquired by the former partners during the partnership, or by the compensatory allowances due between the former partners which are based on the services that they gave to each other during the partnership. On this article, we analyze the variety of solutions developed by the spanish higher courts through their decisions and by the Spanish jurisprudence, in order to solve the multiplicity of problems caused by the lack of state regulation over the dissolution of unregistered partnerships.

KEY WORDS: Unregistered partenerships - More uxorio cohabitation - Broken partnerships - Asset related consecuences

\section{RÉSUMÉ}

Le rupture de cohabitation peut soulever diverses réclamations, qui peuvent être à la liquidation des biens entre eux, ou les demandes d'indemnisation pour la fourniture de services au profit de l'autre lors de la coexistence. Dans cet article, nous analysons les différentes solutions de la doctrine et de la jurisprudence espagnole-inclus les lois régionales et des Conseils-ont

\footnotetext{
*El artículo fue aprobado para su publicación el 15 de abril de 2013.

** Abogado. Licenciado en Derecho de la Pontificia Universidad Católica de Chile. Doctor en Derecho por la Universidad de Salamanca, España. Profesor de Derecho Civil de la Universidad Católica de la Santísima Concepción. Correo electrónico: dvargas@ucsc.cl.
} 
développés devant la multiplicité des problèmes dus au manque de régulation étatique dans la dissolution de l'union civile.

MotS CLÉS: Unions de fait - Coexistence more uxorio - Dissolution unions de fait - Conséquences de propriété

\section{INTRODUCCIÓN}

Con fecha 7 de marzo de 2012 se produjo un hecho inédito en la jurisprudencia chilena, y que está dando lugar a diversos comentarios, ya que la Corte Suprema ${ }^{1}$, rechazando los recursos de casación en la forma y en el fondo interpuestos en contra de la sentencia dictada por la Corte de Apelaciones de Valparaíso, de 4 de noviembre de 2010, acogió la demanda interpuesta por una conviviente en contra de la sucesión hereditaria quedada al fallecimiento de su pareja, donde se reconoció su derecho a percibir una compensación económica fundándose para ello en los elementos esenciales de la equidad.

El máximo Tribunal señaló que la gestión patrimonial de los concubinos, derivada de una larga convivencia, configura una realidad que no puede soslayarse bajo el mecanismo judicial de la ausencia de ley, que hace necesario e impone al juez la obligación de buscar soluciones jurisprudenciales basadas en la equidad, con miras a evitar injusticias tras la culminación de una vida en común; que frente a esta ausencia de ley, el juzgador confirió una solución para el caso concreto, mediante la creación directa de la norma para el caso particular, ajustándose a la equidad natural, reconociendo el derecho a compensación económica y solucionando los efectos patrimoniales de los concubinos.

Que, en todo caso, el reconocimiento del derecho de la concubina a percibir una compensación económica no significa que se valore y otorgue efectos a la compensación económica fuera del ámbito que la rige (el matrimonial), sino que sólo es el reconocimiento de un derecho a quien no ha sido excluido necesariamente por el alcance de la ley, a fin de amparar beneficios patrimoniales, pero en tutela de especiales intereses de orden social.

Dicho lo anterior, la sentencia referida ha puesto de relieve nuevamente uno de los muchos problemas que presentan en nuestro ordenamiento jurídico las uniones de hecho, a saber, cómo resolver la situación patrimonial de los convivientes cuando se produce su disolución, cuestión que nuestra jurisprudencia ha resuelto aplicando diversas instituciones al caso en particular, las que van desde las reglas de la comunidad de bienes, de la sociedad de hecho, de los servicios remunerados, o reconociendo el derecho a una compensación económica fundada en la equidad como se previene en la sentencia citada.

${ }^{1}$ Corte Suprema, "Sánchez Ponce, Rosa con Sucesión Parada Merino", 7 de marzo de 2012, Rol No 337 2011, LegalPublishing CL/JUR/517/2012. 
Ahora bien, como frente a esta realidad nos preguntamos si las soluciones adoptadas hasta el día de hoy por nuestra jurisprudencia son atípicas o extraordinarias o, por el contrario, son similares a las adoptadas en los ordenamientos comparados, en este trabajo se revisará, aunque sea brevemente, cómo se está resolviendo esta cuestión en el ordenamiento jurídico español, ya que al igual que Chile, carecen de una legislación estatal común que regule la situación patrimonial de las uniones de hecho.

\section{Delimitación del tema}

En España, la creciente multiplicación de las uniones de hecho ${ }^{2}$, que las ha transformado en una realidad social, unido a la ausencia de una legislación estatal, ha motivado que en los últimos veinte años la doctrina y jurisprudencia se preocupen de este tema, desarrollando diversas soluciones para la multiplicidad de problemas que ésta presenta, aspiración que también es compartida por las crecientes leyes autonómicas y forales ${ }^{3}$.

\footnotetext{
${ }^{2}$ La doctrina y jurisprudencia emplean diversos términos para referirse a esta figura, tales como: familia no matrimonial, familia de hecho, familia no fundada en el matrimonio (CERDA Gimeno, José (1993). "La situación actual de las parejas no casadas ante el Derecho". En: Estudios sobre Derecho de Familia, Colegio de Registradores de la Propiedad y Mercantiles de España, Centro de Estudios Registrales, Madrid: Ed. San José, pp. 550 y ss.), convivencia marital, la pareja en relación de afectividad análoga a la conyugal, matrimonio sin papeles, matrimonio informal (GARCÍA-POSADA GÓmEZ, Elda (2003). "El concepto de convivencia no matrimonial en Derecho español”. En: $A D C$, T. LVI, fascículo III, julio-septiembre, pp. 1045, 1097), uniones conyugales de hecho (expresión recogida en la nota 2 a la tabla I del anexo a la Ley sobre Responsabilidad Civil y Seguro en la Circulación de Vehículos a Motor, en texto refundido y aprobado por Decreto 632/1968, de 21 de marzo), unión matrimonial de hecho (Reina, Víctor y MarTinell, Josep (1995). Curso de derecho matrimonial. Madrid: Marcial Pons, pp. 67 y ss. Los mismos autores critican los términos "matrimonio de hecho, convivencia more uxorio, vida marital, matrimonio no registrado", fundados en que en el ánimo de la pareja, lo que con frecuencia se pretende evitar, lo que se rehúye es precisamente la idea de matrimonio. Sin embargo, no podemos evitar señalar que ellos prefieren usar el término "uniones matrimoniales de hecho" que, sin duda, igualmente contiene la idea de matrimonio), uniones more uxorio (Díez-Picazo, Luis y Gullón, Antonio (2006). Sistema de Derecho Civil. Vol. IV, Derecho de familia. Derecho de sucesiones, Madrid: Editorial Tecnos, 10a Edición, p. 71), concubinato, estado de mancebía, manceba o concubina (Estrada Alonso, Eduardo (1991). Las Uniones Extramatrimoniales en el Derecho Civil Español. Madrid: Editorial Civitas, 2a Edición, p. 46, señala y critica el uso de estos términos por parte de la doctrina y juristas, ya que se trata de vocablos descalificadores que recuerdan la etapa de persecución penal. El mismo autor, p. 45, cita la expresión "Barraganía" como el término más usado en el Derecho Medieval español para describir la institución que se correspondía con el fenómeno social en comento, y "barragana" el que se atribuía a la mujer que vivía en dicho estado. Según GiTrama GonZÁLEZ, Manuel (1984). "Notas sobre la problemática jurídica de la pareja no casada". En: Estudio de Derecho Civil en Homenaje al profesor J. Beltrán de Heredia y Castaño, Salamanca: Ediciones Universidad de Salamanca, p. 216, la "barraganía" era una especie de sociedad conyugal constituida por un hombre y una mujer con el objeto de hacer vida en común, cuyos caracteres de unidad, permanencia, fidelidad, fines de convivencia y procreación eran similares a los del matrimonio, faltando sólo el requisito esencial de la consagración de tal unión por la Iglesia), entre otros.
}

${ }^{3}$ El estudio de las uniones de hecho o convivencia more uxorio, lo hemos realizado con exclusión de las Leyes autonómicas y forales, a saber, Ley No 10/1998 Catalana de uniones estables de pareja, Ley No 6/1999 Aragonesa de parejas estables no casadas, Ley Foral 6/2000 de Navarra para la igualdad jurídica de las 
Ahora, del sinnúmero de dificultades que se pueden presentar, nos vamos a centrar en aquellas que vienen motivadas con ocasión de su disolución; las parejas felices no tienen problemas ${ }^{4}$.

Si bien, la ruptura no produce en general ninguna obligación alimenticia, compensatoria o indemnizatoria entre los convivientes, la doctrina y la jurisprudencia reconocen que la disolución de esta familia de hecho tiene consecuencias patrimoniales que de alguna forma deben ser resueltas, al igual que ciertos menoscabos patrimoniales del conviviente abandonado, que bajo determinadas circunstancias, deben ser reparados.

Es por ello que, verificada la ruptura, los convivientes pueden plantear diversas reclamaciones, que dependiendo del objetivo que por medio de ella pretendan, podemos separarlas en dos grupos: uno, liquidación del régimen de bienes existente entre ellos; y dos, pretensiones compensatorias por la prestación de servicios realizados por uno en beneficio del otro durante la convivencia.

Para dar respuesta a estos objetivos, la doctrina y jurisprudencia han recurrido a diversas soluciones del Derecho patrimonial, que van desde la aplicación de las normas que expresamente hayan estipulado los convivientes, de las que se deduzcan de hechos o circunstancias demostrativas de su voluntad tácita, o de las que resulten de los Principios Generales del Derecho.

No obstante, antes de entrar al estudio de las soluciones planteadas, debemos determinar qué lugar ocupan las uniones de hecho en el Derecho de Familia en general, y en particular con el matrimonio.

\section{Protección CONSTitucional a la FAMilia EN GENERAL}

Pese a que las uniones de hecho carecen hasta el día de hoy de una regulación estatal propia, ello no es obstáculo para defender su reconocimiento constitucional por medio del artículo 39.1 al disponer que "los poderes públicos aseguran la protección social, económica y jurídica de la familia".

En efecto, la doctrina mayoritaria sostiene que "la protección social, económica y jurídica" que el artículo en referencia confiere a la familia, es a la familia natural, ya que emplea términos genéricos, amplios, sin calificativos, comprendiéndose a

parejas estables, Ley No 1/2001 de Valencia de uniones de hecho, Ley No 11/2001 de Madrid de uniones de hecho de la comunidad de Madrid, Ley No 18/2001 de Baleares de parejas estables, Ley No 4/2002 de Asturias de parejas estables, Ley No 5/2002 de Andalucía de parejas de hecho, Ley No 5/2003 de Canarias para la regulación de las parejas de hecho en la comunidad autónoma de Canarias, Ley No 5/2003 de Extremadura de parejas de hecho de la comunidad autónoma de Extremadura, Ley No 2/2003 del País Vasco reguladora de las parejas de hecho y Ley No 1/2005 de Cantabria de parejas de hecho, por su carácter particular, aplicable a un determinado sector de la población.

${ }^{4}$ Noir-Masnata, Catherine (1986). Los efectos patrimoniales del concubinato y su influencia en el deber de sostenimiento entre esposos separados. Самpos Сово, Juan de Dios (Trad.), Madrid: Editorial Revista de Derecho Privado, p. 56, cita "Las parejas felices no tienen historia". 
la matrimonial y de hecho, pese a que autores como FERRER OrTIZ sostengan lo contrario 5 .

Apoya la posición mayoritaria, el hecho de que el constituyente cuando quiso referirse exclusivamente al matrimonio, lo hizo en un capítulo, título y artículo distinto de aquel concerniente a la familia en general; si quería referirse sólo al matrimonio en ambas normas, lo más lógico es que los hubiera regulado conjuntamente, como sucedía en el artículo 43 de la Constitución española de 1931.

Llegamos a la misma afirmación al examinar las sentencias del Tribunal Constitucional; si bien, no olvidamos que la sentencia de este Tribunal 184/1990, de 15 de noviembre, dispuso lo contrario ${ }^{6}$, todas las posteriores a ella han extendido la protección del artículo 39.1 a la familia matrimonial y de hecho. Así se observa en la sentencia 222/1992, de 11 de diciembre, al declarar: "ningún problema de constitucionalidad existiría si el concepto de familia presente en el artículo 39.1 de la Constitución hubiera de entenderse referido, en términos exclusivos y excluyentes, a la familia fundada en el matrimonio. No es así, sin embargo. Nuestra Constitución no ha identificado la familia a la que manda proteger con la que tiene su origen en el matrimonio, conclusión que se impone no sólo por la regulación bien diferenciada de una institución y otra (articulos 32 y 39), sino también, junto a ello, por el mismo

\footnotetext{
${ }^{5}$ Ferrer Ortiz, Javier (1997). "Familia y Derecho". En: XV Jornadas de la Asociación Española de Canonistas en el XXV Aniversario de su fundación, Madrid 19-21 de abril de 1995, Salamanca: Publicaciones Universidad Pontificia de Salamanca, pp. 197 y ss., quien manifiesta "No por obvio es menos cierto que la Constitución cuando alude a la familia está pensando en la familia española por antonomasia, fundada en el matrimonio y formalidad por el marido, la mujer y los hijos en común, a los que a veces se añade alguno de sus ascendientes. Así viene a confirmarlo la garantía constitucional de la que goza el matrimonio (artículo 32) y de la que carece la familia no matrimonial... En esta misma línea, se ha argumentado que el artículo 39 consta de dos partes netamente diferenciadas: un primer párrafo, donde tutela a la familia basada en el matrimonio, y tres párrafos más donde protege a una serie de personas, constituyan o no una familia, que pueden ser injustamente marginadas. Pero, como regla general, la familia fundada en el matrimonio debe ser objeto de un trato preferencial”.

${ }^{6}$ En ella se declaró que "el matrimonio es una institución social garantizada por la Constitución, y el derecho del hombre y de la mujer a contraerlo es un derecho constitucional (artículo 32.1) cuyo régimen jurídico corresponde a la ley por mandato constitucional (artículo 32.2). Nada de ello ocurre con la unión de hecho more uxorio, que ni es una institución juridicamente garantizada ni hay un derecho constitucional expreso a su establecimiento"; no obstante, hubo un voto particular del magistrado Vicente Gimeno Sendra, que defendía lo contrario, al sostener que "mi única y respetuosa discrepancia se ciñe a determinadas afirmaciones efectuadas en su fundamento jurídico 3. ${ }^{\circ}$, conforme a las cuales las denominadas "uniones conyugales de hecho" carecen de protección constitucional alguna. Ciertamente el "derecho a contraer matrimonio" es un derecho expresamente reconocido en la Constitución (artículo 31.1), pero de esa declaración no se infiere, en mi opinión, que la Constitución no reconozca "un pretendido derecho a formar una unión de hecho", ni que la familia no matrimonial permanezca, a nivel constitucional, desprotegida. Para alcanzar esta conclusión se haría preciso identificar el concepto de "familia" del artículo 39.1 con el de familia "matrimonial" (o lo que es lo mismo, proyectar el artículo 32.1 sobre el 39.1); pero esta identificación, no sólo no se cohonesta con la protección de los hijos ilegítimos o de las madres solteras que el párrafo segundo del mismo precepto también declara, sino tampoco la impone la redacción de la norma constitucional que utiliza simplemente el término "familia" (y no el de familia fundada en el matrimonio) y tan familia es la unión de dos cónyuges que, en su día, suscribieron el correspondiente convenio de matrimonio, como la unión afectiva y estable de una pareja (o de un padre o madre viuda, soltera, separada o divorciada, con sus hijos)".
} 
sentido amparador o tuitivo con el que la Norma fundamental considera siempre a la familia $y$, en especial, en el repetido artículo 39, protección que responde a imperativos ligados al carácter 'social de nuestro Estado (artículos 1.1 y 9.2) y a la atención, por consiguiente, de la realidad efectiva de los modos de convivencia que en la sociedad se expresen. El sentido de estas normas constitucionales no se concilia, por tanto, con la constricción del concepto de familia a la de origen matrimonial, por relevante que sea en nuestra cultura -en los valores y en la realidad de los comportamientos sociales-esa modalidad de vida familiar... Del propio artículo 39.1 no cabe derivar, por tanto, una diferenciación necesaria entre familias matrimoniales y no matrimoniales" ${ }^{\prime}$. En el mismo sentido se ha pronunciado el citado tribunal, en las sentencias 6/1993, de 18 de enero, 47/1993, de 8 de febrero, y 116/1999, de 17 de junio.

Establecida la extensión de la protección constitucional a la familia matrimonial y de hecho, el contenido de la misma es la consagración de "una especie de Derecho fundamental de la persona, con todo lo que ello conlleva de facultad para su titular y correspondiente exigencia de ésta a los Poderes públicos para su real efectividad"8, en los ámbitos económicos, sociales y jurídicos.

\section{SOlUCiONES PROPUESTAS POR LA DOCTRINA Y JURISPRUdENCIA A LA DISOLUCIÓN DE LA UNIÓN DE HECHO}

Para materializar el principio de protección constitucional del artículo 39.1, como para llenar la anomia que regule esta materia, la jurisprudencia y doctrina han recurrido a diversas alternativas del Derecho patrimonial, a fin de determinar la normativa aplicable a los problemas que se plantean con la disolución. Para tal efecto, podemos distinguir tres escenarios posibles, a saber: que los convivientes mediante pacto expreso las hayan estipulado; que éstas se deduzcan de hechos o circunstancias que demuestren su voluntad tácita de sujetarse a una figura jurídica en particular; en defecto de las opciones anteriores, y en última instancia, recurrir a las herramientas comprendidas en los Principios Generales del Derecho.

\subsection{Convenio o pacto expreso de los convivientes}

Debemos destacar que la primera regla para liquidar los efectos económicos, se encuentra en la propia autonomía de la voluntad de la pareja ${ }^{9}$; los convivien-

\footnotetext{
${ }^{7}$ No obstante, hubo dos votos particulares a la sentencia en referencia, de los magistrados Álvaro Rodríguez Bereijo y José Gabaldón López, quienes sostuvieron que la protección del artículo 39.1 de la Constitución estaba limitada a la familia matrimonial, excluyendo a las uniones de hecho.

${ }^{8}$ Martínez-Calcerrada, Luis (1981). "La familia en la Constitución española". Revista de Derecho Privado, noviembre, p. 967.

${ }^{9} \mathrm{La}$ doctrina es uniforme en resaltar que los convivientes son los primeros quienes pueden regular los efectos patrimoniales de su relación mediante pactos o convenios; véase; TORRES GARCía, Teodora (2000). "Régimen económico matrimonial y uniones de hecho". En: Matrimonio y Uniones de Hecho, Martínez Gallego, Eva María (Coord.), Salamanca: Ediciones Universidad de Salamanca, $1^{\text {a }}$ Edición,
} 
tes, mediante el otorgamiento de pactos o convenciones expresos, que algunos han denominado "capitulaciones concubinarias" 10 , son los primeros que pueden determinar cómo se regularán los conflictos que se susciten a la disolución de la unión, la forma de distribuir las adquisiciones y utilidades, y en general, todos y cada uno de los efectos y obligaciones patrimoniales que asuman al término de ésta. Precisamente, sólo a falta de convenios o pactos de los convivientes o cuando éstos no regulen todos los efectos económicos patrimoniales derivados de la disolución, podremos recurrir a las demás alternativas de solución ${ }^{11}$.

Si bien, existe uniformidad en cuanto a la admisibilidad de los convenios o pactos, no podríamos decir lo mismo respecto a su contenido, lo anterior, debido a que cierto sector de la doctrina, durante cierto tiempo, discutió la alternativa de que los concubinos mediante estas estipulaciones, pudieran hacer aplicable cualquiera de los regímenes matrimoniales, en especial, el de sociedad de gananciales.

Así, en consideración a que matrimonio y unión de hecho son figuras totalmente distintas que producen diversos efectos, según ha reconocido reiteradamente el Tribunal Supremo español ${ }^{12}$, se concluía que no era posible aplicar, aun por disposición expresa de los concubinos, cualquiera de los regímenes económicos matrimoniales, ya que se trataba de regímenes normativos previstos exclusivamente para el matrimonio y no para otras figuras jurídicas, sean afines o no ${ }^{13}$. Se agregaba que la falta de publicidad y constancia formal de la existencia de los pactos, contribuían a negar eficacia jurídica a cualquier convenio en que se haya estipulado la aplicación de un régimen económico matrimonial.

pp. 44 y ss.; Lacruz Berdejo, José Luis et al. (2008). Elementos de Derecho Civil IV. Derecho de familia. Madrid: Editorial Dykinson, 3a Edición revisada y puesta al día por Joaquín RAMS AlbESA, pp. 291 y ss.; Reina y Martinell (1995), pp. 76, 92 y ss. (ambos autores reiteran las mismas ideas en Reina, Víctor y Martinell, Josep (1996). Las uniones matrimoniales de hecho. Madrid: Marcial Pons); Cerda Gimeno (1993), pp. 589 y ss.; Gitrama González (1984), pp. 225 y ss.; Mesa Marrero, Carolina (2006). Las uniones de hecho, Análisis de las relaciones económicas y sus efectos. Navarra: Thomson-Aranzadi, $3^{\text {a }}$ Edición actualizada y aumentada, pp. 82 y ss.; NoIr-Masnata (1986), pp. 94 y ss.; Puga Gómez, Santos (2003) "La convivencia more uxorio y la sentencia del Tribunal Supremo de fecha 17 de enero de 2003 ". En: Boletín Aranzadi Civil-Mercantil, núm. 49/2002 (Boletín), Pamplona: Editorial Aranzadi S.A. (BIB 2003/428), p. 1.

${ }^{10}$ Cerda Gimeno (1993), pp. 579 y ss., no considera adecuada la denominación "capitulaciones concubinarias", la estima como una calificación indebida, prefiriendo optar por la designación de "convención especial".

${ }^{11}$ Mediante pactos o convenios otorgados al inicio de la convivencia o después de iniciada ésta, también pueden establecer las reglas que regirán sus relaciones patrimoniales durante la vigencia de la unión de hecho.

${ }^{12}$ Sentencias del Tribunal Supremo, de 11 de octubre de 1994; de 20 de octubre de 1994; de 30 de diciembre de 1994; de 4 de marzo de 1997, y de 4 de junio de 1998.

${ }^{13}$ Torres García (2000), pp. 45 y ss. 
Sin embargo, desde la sentencia del Tribunal Supremo de 21 de octubre de $1992^{14}$, reafirmada hoy en día por la jurisprudencia de este mismo Tribunal expresada en sus sentencias de 22 de enero de 2001, 12 de septiembre de $2005^{15} \mathrm{y}$ 5 de diciembre de 2005, entre otras, la tendencia actual de la doctrina es prácticamente indiscutible; en efecto, hoy en día se admite la estipulación de cualquiera de los regímenes económicos matrimoniales; su argumentación radica en que la estipulación de los convivientes debe ser respetada, ya que en ella se contiene la libre elección y voluntad de los convivientes, valor superior que debe ser protegido y respetado por el ordenamiento jurídico ${ }^{16}$. En este sentido, MeSA MARRERO ${ }^{17}$ expresa, refiriéndose a la actual posición del Tribunal Supremo, que "son plenamente válidos los convenios mediante los cuales las partes acuerden someter sus relaciones patrimoniales a un régimen económico de los previstos por la ley para el matrimonio", siendo en definitiva plenamente aplicables, siempre que los convivientes lo hayan pactado. Comparte la misma conclusión PANTALEÓN ${ }^{18}$ al comentar la sentencia de la Audiencia Provincial de Córdoba de 21 de abril de 1986, y señalar que "la sentencia analizada se limita a afirmar la licitud y eficacia (naturalmente inter partes: artículo $1257^{19}$ del CC) de los pactos con los que las parejas no casadas tratan de reglamentar los aspectos patrimoniales (no los personales) de su relación de convivencia. En concreto, la licitud y eficacia del convenio consistente

\footnotetext{
${ }^{14}$ Mediante esta sentencia, el Tribunal Supremo expresó de forma clara, que las reglas que se deben aplicar a los convivientes al disolverse esta unión de hecho son las previstas por ellos mismos, al decir: "Por ello, entendemos que la normativa reguladora del régimen económico-matrimonial (Título III del Libro Cuarto del Código Civil) no puede considerarse automáticamente aplicable a toda unión libre, por el mero hecho del surgimiento de la misma, ello sin perjuicio de que, atendidas las circunstancias de cada caso concreto, pueda predicarse la aplicabilidad (no por "analogía legis», que aqui no se da, sino por "analogía iuris») de algún determinado régimen económico de los diversos que, para el matrimonio regula el citado Titulo del Código Civil, siempre que quede patentizado, por pacto expreso o tácito (deducido éste de sus hechos concluyentes e inequivocos) que la voluntad de los convivientes fue someterse al mismo, por lo que esta Sala entiende que no cabe la posibilidad de considerar que toda unión paramatrimonial ("more uxorio»), por el mero y exclusivo hecho de iniciarse, haya de llevar aparejado el surgimiento automático de un régimen de comunidad de bienes (llámese gananciales, sociedad universal de ganancias, condominio ordinario o de cualquier otra forma), sino que habrán de ser los convivientes interesados los que, por su pacto expreso o por sus "facta concludentia" (aportación continuada y duradera de sus ganancias o de su trabajo al acervo común) los que evidencien que su inequivoca voluntad fue la de hacer comunes todos o algunos de los bienes adquiridos (suponemos que a título oneroso) durante la duración de la unión de hecho".

${ }^{15}$ En ésta se declaró que "los efectos económicos serán únicamente, en su caso, los que los propios miembros de la pareja hayan previsto mediante pacto, con la misma libertad con la que decidieron unirse y con los límites generales del artículo 1255 CC", reiterando el principio que "a falta de pacto entre los miembros de la unión, cada uno asume las consecuencias económicas de la ruptura, porque, si libre fue la unión, igualmente libre tiene que ser la ruptura para cualquiera de ellos".

${ }^{16}$ Cerda Gimeno (1993), p. 590, manifiesta su conformidad con esta opinión.

${ }^{17}$ Mesa Marrero (2006), p. 172.

${ }^{18}$ Pantaléon Prieto, Fernando (1986). "La autorregulación de la unión libre". Revista del Poder Judicial, No 4, diciembre, pp. 119 y ss.

${ }^{19}$ Artículo 1257 CC: “Los contratos sólo producen efecto entre las partes que los otorgan y sus herederos...”.
} 
en someter sus relaciones patrimoniales al régimen de comunidad de gananciales, como si de marido y mujer se tratara. Habida cuenta que dos personas capaces de obrar a las que no esté prohibido otorgarse recíprocamente alguna donación o ventaja (artículo $1677^{20}$ del CC) pueden pactar con plena libertad en nuestro Derecho una sociedad universal de ganancias (artículo $1675^{21}$ del CC), la decisión nos parece absolutamente correcta”.

Además, debemos indicar que no sólo se pueden hacer aplicables cualquiera de los regímenes económicos matrimoniales mediante convención, sino que también, cualquiera de los cuerpos normativos de carácter patrimonial previstos por la legislación española -v. gr. comunidad de bienes, sociedad universal de bienes o particular de hecho, etc.-; asimismo, pueden otorgar convenciones innominadas, sui generis, que tengan por finalidad regular las consecuencias patrimoniales de la pareja de hecho; e incluso, pueden renunciar anticipadamente a la compensación económica que pudiera corresponderles a cualquiera de los convivientes en caso de ruptura, ya que no contraviene lo dispuesto en el artículo $6.2^{22}$ del Código Civil $^{23}$.

En todo caso, se debe tener presente que mediante pacto o convenio sólo se pueden regular los aspectos patrimoniales entre los convivientes, pero no se puede pretender crear o regular aspectos personales que rijan su convivencia, como los del matrimonio, ya que éstos son inexistentes ${ }^{24}$.

\footnotetext{
${ }^{20}$ Artículo 1677 CC: "No pueden contraer sociedad universal entre sí las personas a quienes está prohibido otorgarse reciprocamente alguna donación o ventaja".

${ }^{21}$ Artículo 1675 CC: "La sociedad universal de ganancias comprende todo lo que adquieran los socios por su industria o trabajo mientras dure la sociedad. Los bienes muebles o inmuebles que cada socio posee al tiempo de la celebración del contrato, continúan siendo de dominio particular, pasando sólo a la sociedad el usufructo".

${ }^{22}$ Artículo 6.2 CC: "La exclusión voluntaria de la ley aplicable y la renuncia a los derechos en ella reconocidos sólo serán válidas cuando no contrarien el interés o el orden público ni perjudiquen a terceros”.

${ }^{23}$ Mesa Marrero (2006), p. 95.

${ }^{24}$ Mesa Marrero (2006), p. 89; Rodríguez Guitián, Alma María (2003). "Función de la responsabilidad civil en determinadas relaciones de convivencia: daños entre cónyuges y daños entre los miembros de la pareja de hecho". En: Revista de Derecho Patrimonial, No 10, Pamplona: Editorial Aranzadi, p. 83.

En sentido contrario se manifiesta Pérez Vallejo, Ana María (1999). Autorregulación en la convivencia de hecho (a propósito de las recientes disposiciones prelegislativas y legislativas tendencialmente más dispositivas). Universidad de Almería, Almería: Servicio de Publicaciones, pp. 73 y ss. (aunque reconoce que su opinión es minoritaria), al decir "Recapitulando consideramos que un convenio en que los convivientes asumieran libre y responsablemente las recíprocas obligaciones que contienen los artículos 67 y 68 del Código Civil no podría estimarse ilícito. Y es que, ciertamente no contraviene ninguna ley que expresamente lo prohíba, no puede estimarse ya contrario a la moral, ni tampoco conculca el orden público. Si bien, la celebración de estos pactos nunca tendrán la consideración de capitulaciones. Tanto es así que el incumplimiento de dichos convenios sobre relaciones personales daría lugar a una suerte de obligación natural, que al momento de la ruptura se torna en obligación jurídica, constituyendo de esta forma causa de la indemnización que voluntariamente prestase uno de los convivientes al otro por incumplimiento del contrato, preferentemente a la disolución de la convivencia”.
} 
Determinado el contenido que los convivientes pueden estipular en sus pactos o convenciones, éstos deben tener igualmente presente ciertos límites impuestos, a fin de que sean plenamente válidos ${ }^{25}$.

Éstos emanan en particular del artículo $1255^{26}$ del Código Civil, y vienen a constituir deslindes al principio general de la autonomía de la voluntad, a saber: que no sean contrarios a las leyes, o sea, que no afecten normas prohibitivas ni constituyan renuncia de bienes indisponibles o irrenunciables, por ejemplo, renuncia a contraer matrimonio; a la moral, como los pactos patrimoniales que se acordaran bajo la condición de comenzar o continuar relaciones sexuales; ni al orden público, como la infracción de normas imperativas, v. gr., la contravención al principio de igualdad previsto en la Constitución ${ }^{27}$.

En el mismo sentido, se debe tener presente el artículo $1271^{28}$ del Código Civil, que permite declarar nulos los pactos suscritos que afecten a la persona o su intimidad, por estar fuera del comercio de los hombres, además de vulnerar la Constitución española, que proclama entre los derechos fundamentales de la persona la dignidad de las mismas y el derecho a la intimidad ${ }^{29}$.

Especialmente, se debe tener en cuenta que el pacto jamás puede estar destinado a que el conviviente que disuelve la unión tenga que pagar una indemnización al otro para poder disolverla, ya que sería como estar comprando su libertad, pagando un "precio de ruptura" ${ }^{30}$, constituyendo un obstáculo a la libertad de disolución, facultad irrenunciable emanada del libre derecho de la personalidad constitucionalmente garantizada, además de adolecer de causa ilícita.

Una cosa es que se admita que los convivientes estipulen las consecuencias económicas de la ruptura, en particular, "que prevean una indemnización por

\footnotetext{
${ }^{25}$ No podemos dejar de mencionar que, la actual doctrina y jurisprudencia, superó sancionar a estos pactos o convenios como nulos, por ilicitud de la causa por inmoralidad, al admitir y reconocer a las uniones de hecho como forma de desarrollo de la familia, lo cual es concorde con el artículo 39.1 de la Carta Fundamental, que "asegura la protección social, económica y jurídica" de la familia en general y no del matrimonio. En el mismo sentido, la Recomendación No R-3 del Comité de Ministros del Consejo de Europa, de 7 de marzo de 1988, señala que no pueden ser estimados como nulos, por el solo hecho de haberse otorgado bajo la condición de constituir una unión de hecho, los pactos de regulación de las relaciones patrimoniales o los contratos de la misma naturaleza otorgados por éstos.

${ }^{26}$ Artículo 1255 CC: "Los contratantes pueden establecer los pactos, cláusulas y condiciones que tengan por conveniente, siempre que no sean contrarios a las leyes, a la moral ni al orden público".

${ }^{27}$ GAVIdIA SÁnChEZ, Julio Vicente (2003b). "Pactos entre convivientes, enriquecimiento injusto y libre ruptura de las uniones no matrimoniales”. Diario La Ley, No 5861, $1^{\circ}$ de octubre; Dí́z-PiCAzo, Luis (1996). Fundamentos del derecho civil patrimonial. Vol. 1, Introducción, Teoría del Contrato, Madrid: Editorial Civitas, 5a Edición, pp. 128 y ss.; Mesa Marrero, Carolina (2006), p. 229, entre otros.

${ }^{28}$ Artículo 1271 CC: "Pueden ser objeto de contrato todas las cosas que no estén fuera del comercio de los hombres, aun las futuras... Pueden ser igualmente objeto de contrato todos los servicios que no sean contrarios a las leyes o a las buenas costumbres".

${ }^{29}$ Mesa Marrero (2006), pp. 87 y ss.

${ }^{30}$ RodríGuez Guití́n (2003), p. 84.
} 
los perjuicios que la ruptura de la convivencia pueda ocasionar a uno de los convivientes" ${ }^{31}$, y otra muy distinta, que acuerden el pago de una indemnización para poder dar término a su unión de hecho ${ }^{32}$.

Un buen ejemplo de lo anterior, lo constituye la sentencia del Tribunal Supremo de 2 de abril de $1941^{33}$, al declarar que "el móvil determinante del contrato no es otro que el rompimiento de los vínculos inmorales e ilícitos que habian atado por largo tiempo a los contratantes, como lo revela el texto del propio documento, en el cual se hace constar que de don F... parte la iniciativa para la ruptura, mediante la proposición que a la demandante hace y que ésta acepta, pero tan sólo a condición de que el demandado consigne en un Banco la cantidad necesaria para que durante dos años pueda la actora retirar mensualmente la suma de dos mil pesetas para sus gastos, obligación de la que quedaría liberado dicho demandado si la otra parte llegare a residir en Europa durante ese mismo plazo". Si bien el sentenciador declaró nulo el mencionado contrato por objeto y causa ilícita ${ }^{34}$, creemos que también vulneraba el principio de libertad de ruptura, ya que según los términos estipulados, se trataba del pago de un precio por liberación ${ }^{35}$.

Por el contrario, disuelta la unión de hecho, los convivientes son libres para estipular todo lo que quieran, respetando los límites generales ${ }^{36}$.

\footnotetext{
${ }^{31}$ Ibíd., p. 84.

${ }^{32}$ En este sentido, De Verda y Beamonte, José Ramón (2006). "Efectos económicos de la ruptura de uniones de hecho". En: Daños en el Derecho de Familia, De Verda y Beamonte, José Ramón (Coord.), Revista de Derecho Patrimonial, No 17, Monografía Asociada a Revista Aranzadi de Derecho Patrimonial, Navarra: Editorial Thomson-Aranzadi, p. 232.

Gavidia SÁnchez (2003b), quien expresa sobre el particular que: "Desde la primera vez que abordé la cuestión me pronuncié en el sentido de considerar nulos aquellos pactos entre convivientes que hicieran ilusoria la libre ruptura de la unión no matrimonial, por entender que estamos ante una exigencia (irrenunciable) del libre desarrollo de la personalidad, en relación con el derecho a no ser considerado casado... Por lo tanto, tales exigencias constitucionales limitan no sólo la libertad del legislador, sino también la de los particulares, de manera que ni por ley ni por pacto se pueden prever prestaciones para el caso de ruptura de las uniones no matrimoniales, que impliquen obstaculizar su libre ruptura, aunque ciertamente no impongan la obligación de continuarlas".

${ }^{33}$ También existe comentario a la sentencia en Fosar Benlloch, Enrique (1983). "Análisis de la Jurisprudencia española sobre las relaciones económicas en las uniones extramatrimoniales". Revista General de Legislación y Jurisprudencia, No 3, marzo, pp. 246 y ss.

${ }^{34} \mathrm{El}$ Tribunal Supremo señaló que "en mérito de lo expuesto, resulta indudable que el condicionar la parte actora la ruptura de un estado, no sólo anormal, sino contrario a las leyes y a los dictados de la moral menos exigente, a la entrega de una cantidad, prevaliéndose de la sugestión e influencia que ejercía sobre la voluntad de la otra parte, equivale a contratar sobre un acto inmoral e ilícito, estipulándose el pago de cantidad determinada a cambio de una obligación de hacer, consistente en dejar a aquella parte en libertad para el cumplimiento de sus deberes legales y morales, lo cual no puede menos de viciar el objeto y la causa del contrato".

${ }^{35}$ Rodríguez Guití́n (2003), p. 84.

${ }^{36}$ GaVidia SánCheZ, Julio Vicente (2002). "Analogía entre el matrimonio y la unión libre en la jurisprudencia del Tribunal Supremo y principio de libre ruptura de las uniones no matrimoniales". En: Aranzadi Civil, núm. 6/2002 (Estudio), Pamplona: Editorial Aranzadi S.A. (BIB 2002/655), p. 21.
} 
Por último, en virtud del principio de libertad de forma consagrado en el artículo $1278^{37}$ del Código Civil, estos pactos no están sujetos a formalidad alguna, a diferencia de las capitulaciones matrimoniales que necesitan constar por escritura pública para su validez.

\subsection{Hechos o circunstancias que permiten deducir la voluntad tácita de los convivientes de sujetarse a determinadas normas}

Frente a la ausencia de pactos expresos de los convivientes, la doctrina y jurisprudencia recurren a los hechos o circunstancias que permitan deducir las normas a las cuales se han sujetado tácitamente (facta concludentia ${ }^{38}$ ), resolviendo así las pretensiones económicas planteadas por éstos después de la ruptura de la unión de hecho.

Lógicamente, aquel de los convivientes que alegue la aplicación de una normativa en particular, deberá probarla, demostrando la concurrencia y cumplimiento de todos los requisitos impuestos por la ley para su constitución y validez ${ }^{39}$.

\subsubsection{Constitución de una sociedad irregular universal o particular de bienes}

Para que pueda ser aplicada esta alternativa, es menester que se acredite la existencia de todos y cada uno de los requisitos previstos por el legislador para su constitución. Entre éstos, el de mayor dificultad probatoria, según opinión de la doctrina y jurisprudencia, se encuentra en la affectio societatis, requisito que en ningún caso se presume por la sola existencia de la unión de hecho ${ }^{40}$.

Sobre el particular, DE VERDA ${ }^{41}$ agrega, apoyado en las sentencias del Tribunal Supremo de 11 de diciembre de 1992 42, 27 de mayo de 2004, entre otras, como,

\footnotetext{
${ }^{37}$ Artículo 1278 CC: "Los contratos serán obligatorios, cualquiera que sea la forma en que se hayan celebrado, siempre que en ellos concurran las condiciones esenciales para su validez".

38 "Esto es, cuando los hechos realizados por los convivientes en el transcurso de su vida en común demuestren la voluntad negocial de los sujetos en este sentido", Mesa Marrero (2006), p. 173.

${ }^{39}$ De ahí que la doctrina recomiende que los pactos sean lo más expresos posibles, a fin de evitar discusiones una vez disuelta la convivencia more uxoria, obligando a las partes a quedar entregadas a la interpretación de los tribunales, como ocurre bajo este escenario.

${ }^{40}$ Sentencia del Tribunal Supremo, de 27 de mayo de 1994; en ésta se expresó “que las posibles consecuencias económicas de tal convivencia al tiempo de su ruptura pueden en algún caso asemejarse a las sociedades cuando se acredite la "affectio societatis", que no puede inferirse sólo de la convivencia "more uxorio", porque en éstas cabe también aceptar la plena independencia económica de quienes la practican”. Véase, además, Mesa MARrero (2006), pp. 173 y ss., donde trata la sociedad universal de ganancias, y pp. 178 y ss., en las cuales analiza la sociedad particular de hecho; NoIR-Masnata (1986), pp. 61 y ss.

${ }^{41}$ De Verda y Beamonte (2006), pp. 237 y ss.

${ }^{42}$ En ella, el Tribunal Supremo resolvió desestimar la alegación de la recurrente, que sostenía la existencia de una sociedad universal de ganancias durante el tiempo de convivencia en unión extramatrimonial (años 1979 a 1985), "por las siguientes razones: a) La sociedad, cuyo carácter contractual ha de afirmarse-si bien se halle matizado por su naturaleza asociativa derivada de su propia finalidad-, requiere el consentimiento de los
} 
sin embargo, la jurisprudencia "es muy reacia a considerar tácitamente constituida una sociedad universal de ganancias..., ya que comprendería todo lo que ambos integrantes de la unión de hecho adquirieran durante la duración de ésta, con su trabajo o industria”, a diferencia de lo que sucede cuando lo que se alega es una sociedad particular de bienes, donde es más fácil apreciar la concurrencia de la affectio societatis "cuando uno de los convivientes ha participado en la actividad empresarial o comercial del otro, durante tiempo prolongado y de manera

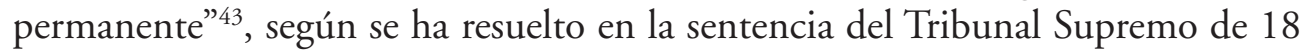
de marzo de $1995^{44}$, en la sentencia de la Audiencia Provincial de Alicante de 17 de mayo de 2001, entre otras.

Pero además de la affectio societatis, es menester que se acredite que los convivientes han puesto en común bienes, dinero o industria, es decir, que han realizado aportaciones al fondo común ${ }^{45}$, demostrando, asimismo, su intención de conseguir un lucro común, repartible entre sí.

contratantes-que ha de ser claro e inequivoco-, el cual, en cierta manera, se identifica con el tradicional requisito de la "affectio societatis» que, en puridad, tiene significación teleológica; b) La existencia de este consentimiento no es una inferencia necesaria de la situación de unión extramatrimonial que, aun siendo susceptible de generar algunos derechos de contenido patrimonial entre quienes la integran, no siempre ha de estimarse concurrente, ya que puede, sin duda, suceder que, en las uniones que dan lugar a la convivencia "more uxorio" prefieran, quienes las forman, mantener su independencia económica, supuesto, por otra parte más conforme con la elusión de la formalidad matrimonial; c) En el caso que nos ocupa, la sentencia impugnada declaró que los incrementos patrimoniales se adquirieron y titularon para cada uno de los litigantes individualmente, y lo cierto es que sus actividades se desenvolvieron en ámbitos perfectamente diferenciados sin que se haya probado acuerdo alguno para que las respectivas adquisiciones se atribuyeran a ambos; $y$ d) Consecuentemente, ha de concluirse que no existió la sociedad universal de ganancias, por ausencia del requisito esencial de consentimiento (artículo $1261-1 .^{\circ}$ del Código Civil), de donde se sigue la desestimación del motivo".

${ }^{43}$ Cuando sólo se ha apreciado una colaboración pasajera u ocasional del conviviente en las actividades empresariales o comerciales del otro, se ha desestimado la concurrencia de la affectio societatis, descartando la existencia de una sociedad particular de bienes, como se observa en la sentencia del Tribunal Supremo, de 11 de diciembre de 1992, ya citada.

${ }^{44}$ En ella se declaró probado que los miembros de la unión "convivieron como si de un matrimonio se tratara hasta, por lo menos, el año 1974, periodo de tiempo prolongado en el que ambos ejercieron juntos diversas actividades industriales y adquirieron bienes conjuntamente o individualmente uno de ellos pero para la sociedad que su prolongada convivencia y trabajo en común habia consolidado".

${ }^{45}$ En la sentencia del Tribunal Supremo, de 18 de febrero de 1993, pese haberse acreditado el requisito de la affectio societatis, la demanda fue desestimada al declarar que "no puede olvidarse que además de la voluntad asociativa, la ley exige en el artículo 1665 del Código Civil la puesta en común de dinero, bienes o industria, para que toda sociedad pueda tener existencia; y aqui es donde quiebra la tesis de la parte recurrente. En la sentencia recurrida se establecen como hechos de partida, deducidos del material probatorio, que doña Teresa F. sólo contribuyó al primitivo negocio de piel denominado "LM Shop», y después al que lo sustituyó, "Heladería Escala», cooperando con su trabajo personal, sin que conste en autos ninguna otra aportación patrimonial, ni intervención personal, en el resto de los negocios que su oponente venía explotando antes de la unión; siendo indispensable, como antes se apuntaba, que aparezca demostrada con actos inequivocos, la voluntad de los convivientes de hacer comunes todos los bienes y ganancias adquiridos por cada uno de ellos durante la convivencia; actos que deben de consistir, bien en una aportación patrimonial al negocio productor de los beneficios, o en otro caso la cooperación con su trabajo personal en las ganancias; circunstancias que no se han acreditado en autos, salvo en el negocio de heladería". 
Por último, como estamos en el supuesto de que no existe pacto expreso, el reparto de las utilidades o pérdidas será en proporción a lo aportado por cada socio conviviente, según lo previene el artículo $1689^{46}$ del Código Civil.

\subsubsection{Existencia de una comunidad de bienes}

Otra de las formas que la jurisprudencia admite para liquidar el régimen económico patrimonial de los convivientes, es mediante las reglas de la comunidad de bienes; para ello es necesario acreditar que los miembros de la unión han manifestado su voluntad en tal sentido, pudiendo recurrir a hechos positivos que demuestren dicho consentimiento, ya sea mediante aportaciones recíprocas, personales o económicas para la adquisición de bienes, siempre con la finalidad de hacerlos comunes ${ }^{47}$.

$\mathrm{Al}$ igual que en el caso de la sociedad universal o particular de bienes, la simple existencia de la convivencia more uxorio no es suficiente para presumir la aplicación del régimen de comunidad ${ }^{48}$.

Un hecho muy demostrativo de la existencia del régimen de comunidad, son las cuentas corrientes conjuntas a nombre de ambos convivientes, y con cargo a la cual, por ejemplo, se paga el precio de una vivienda o se amortiza el préstamo otorgado para su adquisición ${ }^{49}$. Sin embargo, creemos que lo que realmente de-

\footnotetext{
${ }^{46}$ Artículo 1689 CC: "Las pérdidas y ganancias se repartirán en conformidad a lo pactado... A falta de pacto, la parte de cada socio en las ganancias y pérdidas debe ser proporcionada a lo que haya aportado".

${ }^{47}$ Sentencia del Tribunal Supremo, de 17 de mayo de 2004, que acogiendo el recurso de casación, declaró que: "Ha sido reiterada la jurisprudencia que ha estimado la demanda de la conviviente more uxorio frente al conviviente que reclama una parte de los bienes adquiridos durante el periodo de convivencia, que están bajo la titularidad del demandado. Este caso es el inverso: durante el período de convivencia, se adquiere un bien por mitad pro indiviso de los dos -la vivienda común-y, tras la ruptura, uno de ellos pretende que se declare su exclusiva propiedad; la sentencia recurrida estima su demanda, por entender que la verdadera voluntad era que fuera él el único adquirente, lo cual es absurdo pues en el negocio bilateral ella nunca tuvo esta voluntad, y por estimar la falta de causa porque ella "no aportó en su compra su parte correspondiente» e ignora que una convivencia es no sólo una comunidad económica, sino además una comunidad de vida y las aportaciones personales de la convivencia -además de tener un indiscutible valor económico (así, artículo 103, medida 3a, segundo párrafo) - no pueden obviarse al determinar la propiedad de una cosa común".

${ }^{48}$ Sentencia del Tribunal Supremo, de 17 de enero de 2003.

${ }^{49}$ Sentencia de la Audiencia Provincial de Zaragoza, de 23 de enero de 2001; sentencia de la Audiencia Provincial de Asturias, de 26 de junio de 2001; sentencia de la Audiencia Provincial de A Coruña, de 10 de junio de 2002, donde se resolvió que "En el presente caso, se ha acreditado de la prueba practicada como vimos, que doña Alejandra Montserrat N. H. y don Jesús F. C. convivieron durante siete años aproximadamente, manteniendo una relación análoga a la matrimonial, con una permanencia consolidada en la que no se probaron interrupciones, creando además de los naturales vinculos afectivos, una comunidad de intereses económicos derivando asi en un estado de hecho semejante al generado por una unión matrimonial, aperturando cuenta corriente de la que ambos eran titulares, ingresando en la misma sus percepciones económicas derivadas de su trabajo personal, de la que disponían para hacer frente a los gastos comunes, y precisamente residian en la vivienda sita en la calle Pedro Carvajal núm...., de Ferrol, que decidieron adquirir precisamente con patrimonio común, si bien haciendo constar en la escritura de compraventa como única adquirente a doña Alejandra, dado
} 
muestra la vigencia del régimen de comunidad no es la titularidad conjunta, sino que la contribución real y efectiva de fondos y aportes de ambos convivientes a dicha cuenta ${ }^{50}$, como se aprecia en la sentencia de la Audiencia Provincial de Pontevedra de 6 de abril de 1998, que resolvió aplicar el régimen de comunidad de bienes sobre un inmueble, aunque éste hubiese sido adquirido con cargo a una cuenta individual de una de las partes y a cuyo nombre aparecía exclusivamente la propiedad, ya que se probó que ambos convivientes habían contribuido con recursos a la referida cuenta individual.

Cumplido lo anterior, se podrá alegar la existencia de una comunidad, copropiedad o condominio, procediéndose a la división de los bienes comunes, reputándose para tal efecto, iguales las cuotas de los comuneros -salvo prueba en contrario-, y aun cuando dichos bienes figuren inscritos a nombre de uno solo de ellos, prescindiendo así de la titularidad formal ${ }^{51}$. Entre los defensores de este régimen se encuentra Estrada Alonso ${ }^{52}$, quien hace aplicable las normas de la comunidad prevista en los artículo 392 y siguientes del Código Civil.

\subsubsection{Existencia de una relación laboral}

Algunos autores ${ }^{53}$ sostienen que a fin de proteger los intereses del conviviente que ha prestado servicios en beneficio del otro, dentro o fuera del hogar, se puede alegar la existencia de un contrato de trabajo entre las partes, ya que es posible que concurran todos los requisitos para ello, a saber, relación de subordinación y dependencia entre los partícipes de la unión, prestación de servicios por una parte y retribución económica, en una situación similar a la prevista en el artículo 1438 del Código Civil que demuestra la onerosidad de los servicios prestados

el vinculo matrimonial que unía a don Jesús con otra persona, y con ello, intentar evitar posibles reclamaciones de esta última... En definitiva ha existido una comunidad de bienes durante el periodo de siete años aproximadamente de convivencia".

${ }^{50}$ Sentencia de la Audiencia Provincial de Salamanca, de 29 de junio de 1995, que resolvió, apoyada en las sentencias del Tribunal Supremo, de 24 de marzo de 1971, de 19 de octubre de 1988, de 8 de febrero de 1991, de 23 de mayo de 1992 y de 15 de diciembre de 1993, que "la circunstancia de que haya varios titulares de un depósito bancario es más bien operativa para la dinámica del contrato, de forma que cualesquiera de dichos titulares ostenta facultad de disposición frente al banco, bien individual o conjuntamente, pero sin establecer la existencia de un condominio, ya que éste lo fijan las relaciones internas de los titulares y más en concreto la originaria pertenencia de los fondos depositados".

${ }^{51}$ Sentencia del Tribunal Supremo, de 29 de octubre de 1997, instancia que declaró que cuando cesa la convivencia more uxorio, "surge la necesidad de la disolución y adjudicación de la cotitularidad compartida sobre los bienes comunales, sin que represente obstáculo eficiente el que la titularidad de todos o algunos de dichos bienes aparezca a favor de alguno de los componentes de la unión de hecho, debiéndose efectuar en posiciones igualitarias, y a la que se debe aplicar sin duda el régimen que establecen los artículos 392 y siguientes del Código Civil'.

${ }^{52}$ Estrada Alonso (1991), p. 210.

${ }^{53}$ Véase, Estrada Alonso (1991), pp. 210 y ss. 
por un cónyuge dentro del hogar cuando éstos se encuentran bajo el régimen de separación total de bienes.

A favor de esta postura, inicialmente podemos agregar que conforme a la legislación laboral ello es perfectamente posible, ya que no existe impedimento ni prohibición legal que limite o restrinja la celebración de un contrato de trabajo expreso entre convivientes. Sólo se exceptúan del ámbito laboral, a virtud del artículo 1.3.e) de la Ley del Estatuto de los Trabajadores, de 29 de marzo de 1995, los trabajos familiares, entendiendo por tales aquellos realizados entre parientes próximos ${ }^{54}$, que conviven, bajo un vínculo de subordinación (sujeción) y dependencia, y en cuya relación no media salario. En este sentido la sentencia del Tribunal Supremo, de 24 de febrero de 2000, ha sido muy clara al resolver que "la convivencia de hecho o 'more uxorio' no encaja dentro del tipo legal contemplado en el artículo 1.3.e) del ET. Es cierto que en el caso de autos hay convivencia entre la actora y el empresario, sin embargo está ausente la condición de familiar. La norma se está refiriendo cuando habla de familia a la nacida del matrimonio; no prevé la convivencia 'more uxorio"' 55.

Si bien, no nos cabe duda que, en virtud del principio de autonomía de la voluntad que rige la relación entre los convivientes, éstos son libres de celebrar un contrato de trabajo que regule su situación, el que incluso puede existir aun antes de que se inicie la convivencia, el problema radica en determinar si, a falta de contrato laboral expreso, éste se puede presumir de hechos o circunstancias acaecidos durante la unión.

Sobre el particular, Estrada AlONSO ${ }^{56}$ sostiene que se debe desestimar dicha alternativa, en consideración a que en ausencia de estipulación expresa no se puede presumir la voluntad de los integrantes para la celebración de un contrato de trabajo, ni tampoco de que uno de los convivientes perciba algún

\footnotetext{
${ }^{54}$ Por parientes próximos se comprende al cónyuge, los descendientes, ascendientes y demás parientes por consaguinidad o afinidad, hasta el segundo grado inclusive y, en su caso, por adopción.

${ }^{55}$ En este mismo sentido, se han pronunciado las sentencias del Tribunal Superior de Justicia de Andalucía, Sevilla, de 13 de septiembre de 2002 y la sentencia del Tribunal Supremo, de 11 de marzo de 2005; no obstante, en este último fallo, el sentenciador desestimó la existencia de la relación laboral porque no se cumplían los requisitos legales necesarios, especialmente el de ajenidad y dependencia.

En sentido contrario se manifiesta Orcaray Reviriego, Javier (2002). "Convivencia 'more uxorio'. A propósito de la sentencia del Tribunal Supremo de 24 febrero 2000, que otorga el derecho a la prestación por desempleo a trabajadora despedida por el empresario con el que convive". En Boletín Aranzadi Laboral, núm. 7/2002 (parte Boletín), Pamplona: Editorial Aranzadi S.A. (BIB 2002/1261), al señalar que la sentencia comentada pierde "a nuestro juicio, la oportunidad de efectuar una interpretación extensiva, más allá de la aplicación literal del precepto cuestionado, poniendo en relación el concepto de trabajos familiares con la incuestionable realidad que se le planteaba y que no era otra que la situación de convivencia de hecho estable", pudiendo extender el artículo 1.3.e) del ET por aplicación de la "analogía iuris"; concluye, en definitiva, que "no parece que pueda existir esta condición laboral entre los convivientes, llámense o no familiares en sentido estricto".
}

${ }^{56}$ Estrada Alonso (1991), pp. 210 y ss. 
tipo de retribución por los servicios prestados al otro, en una situación análoga al artículo 1438 del Código Civil.

En apoyo de esta postura, a la que nos adherimos, encontramos en el artículo 1.3.d) del Estatuto en referencia, otro argumento que sirve para desestimar la existencia de una relación laboral entre convivientes, al disponer que se excluyen de este ámbito, "los trabajos realizados a título de amistad, benevolencia o buena vecindad” (más aún, cuando en virtud del artículo 1.3. g) se reconoce que la enumeración del artículo 1.3 es enunciativa y no taxativa); sin duda que entre los miembros de una unión libre existe afecto, sentimientos particulares, entre otras consideraciones personales, que nos hacen suponer justificadamente un vínculo de amistad íntima, que conforme a la norma citada lleva a que los servicios prestados por uno de ellos en beneficio del otro, fuera o dentro del hogar, estén exentos de ser considerados como servicios prestados dentro de la vigencia de una relación laboral.

\subsection{Aplicación analógica de las normas sobre liquidación de los regimenes económicos matrimoniales}

Conforme a lo dicho hasta este momento, no cabe duda que la aplicación de las normas de cualquiera de los regímenes económicos es perfectamente posible cuando los convivientes lo hayan pactado expresamente o cuando de sus hechos o circunstancias (facta concludentia) se demuestre su voluntad tácita en tal sentido ${ }^{57}$.

Pero frente a la ausencia de pacto expreso o tácito de los convivientes, ¿̇es posible su aplicación analógica?

Sobre esta cuestión, la doctrina mayoritaria citada en este apartado, conforme con lo resuelto por el Tribunal Constitucional y Supremo, está conteste en que a falta de convención expresa o tácita, no se pueden aplicar a las uniones de hecho las reglas de los regímenes matrimoniales, en particular, el régimen de gananciales, amparados en una interpretación analógica ${ }^{58}$. Esta posición se fundamenta

\footnotetext{
${ }^{57}$ Nos remitimos a la sentencia del Tribunal Supremo, de 21 de octubre de 1992, ya citada.

${ }^{58}$ Véase De Verda y Beamonte (2006), p. 229; Reina y Martinell (1995), pp. 90 y ss.; Cerda Gimeno (1993), p. 589; Torres García (2000), p. 50; Mesa Marrero (2006), pp. 169 y ss.; Estrada Alonso (1991), p. 172 y ss.; Díez-Picazo y Gullón (2006), p. 72; Lacruz Berdejo et al. (2008), pp. 292 y ss.; Gavidia SÁnchez (2002), p. 33.

En cuanto a la jurisprudencia, véase la sentencia del Tribunal Supremo, de 21 de octubre de 1992, al declarar que: "Sin dejar de reconocer la plena legalidad de toda estable unión de hecho entre un hombre y una mujer [como manifestación del derecho fundamental al «libre desarrollo de la personalidad»: artículo 10 de la Constitución] y la susceptibilidad de constituir con ella una familia tan protegible como la creada a través de unión matrimonial (articulo 39 de la citada Constitución), no es menos cierto que dicha unión libre o de hecho no es una situación equivalente al matrimonio [STC 184/1990, de 15 noviembre (RTC 1990\184) y
} 
en el hecho, que como los convivientes han huido voluntaria y libremente del matrimonio, se presume su voluntad de rechazo a aplicar cualquiera de los regímenes que lo regulan; sostienen que si la pareja quisiera los mismos efectos del matrimonio, simplemente se habrían sometido a dicha figura; el que no se casa es porque no quiere que se le aplique el régimen de derechos y obligaciones del matrimonio. Además de lo anterior, añaden que para el Derecho, el matrimonio y la unión de hecho constituyen dos figuras jurídicas distintas, cuyos efectos personales y patrimoniales de una no son susceptibles de ser aplicados a la otra. Lo anterior se puede resumir citando a JORDANO BAREA ${ }^{59}$, quien, reiterando la jurisprudencia del máximo tribunal, expone que "la decisión personal, libremente tomada, de unirse prescindiendo del vínculo legal del matrimonio, ha dado origen a un instituto sustancialmente distinto, en cuanto a la generación de derechos y deberes interpersonales y patrimoniales".

Pese a lo expuesto, RIVERO HERNÁNDEZ ${ }^{60}$ sostiene lo contrario, al expresar que sí son aplicables en virtud de una interpretación analógica, ciertas y determinadas normas de los regímenes matrimoniales a las uniones de hecho, en específico, aquellas que encuentran su justificación en la "convivencia" que existe entre hombre y mujer, la que se da tanto en las parejas de hecho como matrimoniales. Agrega, en todo caso, que "sólo pretende que se apliquen por analogía a una pareja conviviente las normas existentes previstas para otro tipo de convivencia y sólo en cuanto tal: la semejanza se da en la convivencia y sus necesidades y consecuencias, no entre las respectivas instituciones" ${ }^{61}$.

\footnotetext{
Auto 156/1987 del mismo Tribunal] y, al no serlo, no puede ser aplicada a aquélla (en cuanto a las relaciones personales y patrimoniales entre los convivientes) la normativa reguladora de éste, pues los que en tal forma se unieron, pudiendo haberse casado, lo hicieron, precisamente (en la generalidad de los casos), para quedar excluidos de la disciplina matrimonial y no sometidos a la misma". En el mismo sentido, véanse las sentencias del Tribunal Supremo, de 18 de febrero de 1993; de 22 de julio de 1993; de 27 de mayo de 1994; de 11 de octubre de 1994; de 30 de diciembre de 1994; de 4 de marzo de 1997; de 23 de julio de 1998; de 22 de enero de 2001; o la jurisprudencia menor, sentencia de la Audiencia Provincial de Asturias, de 22 de junio de 1994 que resolvió: "esta diferencia de trato se justifica tanto por razones de certidumbre y seguridad jurídica, como por la coherencia de la opción elegida por la pareja, pues parece lógico que si se ha decidido libremente no someterse a los derechos y obligaciones inherentes a la institución del matrimonio, no cabrá luego imponerlos por vía coactiva cuando surjan dificultades o quiebre la convivencia... Esta falta de identidad de razón excluye, en términos generales, la posibilidad de aplicar las normas del matrimonio a las uniones de hecho por vía analógica"; entre otras.

59 Jordano Barea, Juan (1999). "Matrimonio y unión libre”. En: Actualidad Civil, No IX, p. 187.

${ }^{60}$ Rivero Hernández, Francisco (1998). “Comentario a la sentencia de 29 de octubre de 1997”. En: Cuadernos Civitas de Jurisprudencia Civil, T. 46, enero-marzo, pp. 189 y ss.

${ }^{61}$ En apoyo de su opinión, podríamos citar a LACRUZ y SANCHO REBULLIDA que sostienen, según veremos a continuación, la aplicación analógica de ciertas y limitadas normas del matrimonio a la unión de hecho, como el artículo 1438 del Código Civil.
} 


\subsubsection{Aplicación analógica de la pensión compensatoria prevista en el artículo $97^{62}$ del Código Civil}

Sobre el particular, De la Haza Díaz ${ }^{63}$ sostiene al estudiar la pensión compensatoria en el matrimonio, que si el artículo 101 del Código Civil dispone que la convivencia more uxorio es causa de extinción de la pensión, es defendible mantener que ésta tenga alguna incidencia en su nacimiento; agrega en su apoyo la sentencia de la Audiencia Territorial de Valencia, de 3 de junio de 1987 (Sala Primera) ${ }^{64}$, que frente a la anomia que regule las uniones de hecho, y en virtud de la analogía, resolvió aplicar las normas del "régimen económico matrimonial con el fin de resolver las cuestiones suscitadas por demandante y demandado", incluyendo la aplicación de la pensión compensatoria del artículo 97 del Código Civil ${ }^{65}$.

No obstante, el argumento anterior ha sido rechazado por MESA MARRERO ${ }^{66}$, al señalar que la razón que ha tenido el legislador para establecer a la convivencia more uxorio como causa de extinción de la pensión compensatoria, se encuentra en que con ello se quiere evitar situaciones fraudulentas de quienes intencionadamente no quieren contraer matrimonio para no perder su derecho a pensión, pero en ningún caso la unión de hecho se puede equiparar al matrimonio para dar nacimiento a este derecho ${ }^{67}$.

\footnotetext{
${ }^{62}$ Artículo 97 CC: "El cónyuge al que la separación o el divorcio produzca un desequilibrio económico en relación con la posición del otro, que implique un empeoramiento en su situación anterior en el matrimonio, tendrá derecho a una compensación que podrá consistir en una pensión temporal o por tiempo indefinido, o en una prestación única, según se determine en el convenio regulador o en la sentencia. A falta de acuerdo de los cónyuges, el Juez, en sentencia, determinará su importe teniendo en cuenta las siguientes circunstancias: $1^{\circ}$ Los acuerdos a que hubieren llegado los cónyuges. $2^{\circ}$ La edad y el estado de salud. $3^{\circ}$ La cualificación profesional y las probabilidades de acceso a un empleo. $4^{\circ} \mathrm{La}$ dedicación pasada y futura a la familia. $5^{\circ} \mathrm{La}$ colaboración con su trabajo en las actividades mercantiles, industriales o profesionales del otro cónyuge. $6^{\circ}$ La duración del matrimonio y de la convivencia conyugal. $7^{\circ}$ La pérdida eventual de un derecho de pensión. $8^{\circ}$ El caudal y los medios económicos y las necesidades de uno y otro cónyuge. $9^{\circ}$ Cualquier otra circunstancia relevante. En la resolución judicial se fijarán las bases para actualizar la pensión y las garantias para su efectividad'.

${ }^{63}$ De la Haza Díaz, Pilar (1989). La pensión de separación y divorcio. Madrid: La Ley, p. 31, nota 4.

${ }^{64}$ Sentencia de la Audiencia Territorial de Valencia, de 3 de junio de 1987, Revista General de Derecho, 1987 , pp. 5131 y ss.

${ }^{65}$ En el caso de autos, y frente a la ausencia de pacto entre los convivientes, el sentenciador resolvió liquidar la unión de hecho de conformidad a las normas del régimen de la sociedad de gananciales. Sin embargo, no podemos dejar de recordar según hemos expuesto, que el Tribunal Supremo es contrario a la aplicación analógica de los regímenes matrimoniales, salvo pacto expreso o tácito de los convivientes en contrario, como se aprecia en sus sentencias de 11 de diciembre de 1992, de 30 de diciembre de 1994, entre otras.

${ }^{66}$ Mesa Marrero (2006), pp. 211 y ss.

${ }^{67}$ Estrada Alonso, Eduardo (1991), pp. 310 y ss., por su parte, argumenta que se extingue el derecho a pensión compensatoria por la convivencia more uxorio, según previene el artículo 101 del Código Civil, porque entre los convivientes existiría una obligación natural, un deber moral y social presumible, que otorgaría el derecho-deber de ser atendido económicamente por su pareja, el cual respondería a principios de equidad, justicia y solidaridad. Sin embargo, esta opinión es igualmente rechazada por MeSA MARrERo, quien sostiene que al no existir un deber legal de alimentos entre convivientes, no existiría fundamento legal que permita amparar la presunción argumentada por EstRada Alonso.
} 
Ahora, si pasamos revista a la jurisprudencia del Tribunal Supremo, observamos cómo hasta julio de 2001, éste también rechazaba la aplicación del artículo 97 por analogía, momento en que cambió su orientación ${ }^{68}$.

En efecto, mediante sentencia de 5 de julio de 2001, el máximo órgano jurisdiccional cambió su posición, aceptando por medio de la analogía legis prevista en el artículo 4.1 ${ }^{69}$ del Código Civil, la aplicación del artículo 97 a las uniones de hecho, al resolver que "ante la ausencia de normativa reguladora de las parejas de hecho..., ha de acudirse a la fuerza expansiva del ordenamiento jurídico, a través de la aplicación analógica del Derecho y precisamente en estos casos de uniones de hecho 'more uxorio' encuentra su semejanza en su disolución y final por la voluntad unilateral de una de las partes, con algunos efectos recogidos para las sentencias de separación o divorcio por el Código Civil y así su artículo 97 atribuye al cónyuge, al que tal contingencia produzca un desequilibrio económico con relación al otro y que implique un empeoramiento con relación a su situación anterior al matrimonio, el derecho a una pensión, pudiendo convenir en cualquier momento la sustitución de la misma por la constitución de una renta vitalicia, el usufructo de determinados bienes o la entrega de un capital en bienes o en dinero (artículo 99)". Esta postura fue reiterada mediante sentencia de 16 de julio de $2002^{70}$ por el mismo tribunal ${ }^{71}$.

\footnotetext{
${ }^{68}$ Sobre el particular, puede verse la evolución de la jurisprudencia del Tribunal Supremo en LÓPEZ JimÉNEZ, David (2006). "La aplicación analógica de la pensión compensatoria como criterio de resolución de las reclamaciones económicas entre los convivientes”. En: Aranzadi Civil, núm. 16/2006 (Estudio), Pamplona: Editorial Aranzadi S.A. (BIB 2006/1685).

${ }^{69}$ Artículo 4.1 CC: "Procederá la aplicación analógica de las normas cuando éstas no contemplen un supuesto especifico, pero regulen otro semejante entre los que se aprecie identidad de razón”.

${ }^{70}$ En este caso, el tribunal acogió el recurso de casación interpuesto y revocó la sentencia de la Audiencia Provincial de Granada que había aceptado la petición subsidiaria de la acción de enriquecimiento sin causa, y resolvió "más adecuada la aplicación analógica (artículo 4.1 del Código Civil) del artículo 97 del Código Civil” como lo había expresado el Juzgado de Primera Instancia.

${ }^{71}$ GAVIDIA SÁnCheZ, Julio Vicente (2003a). "Comentario a la sentencia de 16 de julio de 2002”. En: Cuadernos Civitas de Jurisprudencia Civil, No 61, enero-abril, pp. 119 y ss., rechaza el recurso a la analogía legis para aplicar el artículo 97 del Código Civil a las uniones de hecho, fundado en la "inexistencia del requisito de identidad de razón" y "la posible inconstitucionalidad por vanificación de la libre ruptura de las uniones no matrimoniales". El autor en comento sostiene el recurso a la analogía iuris, "a un posible principio general, del que la norma contenida en el artículo 97 del Código Civil sería concreción, al menos, en una parte de su potencial aplicativo, para las rupturas matrimoniales, conforme al cual, ha de ser compensado el enriquecimiento que se ha obtenido a costa de otro, que ve empeorada su situación tras la ruptura y que se ha empobrecido como consecuencia de inversiones de dinero o de tiempo en el mantenimiento de comunidades de vida, exclusivas y duraderas, con cuidados y responsabilidades recíprocos, que van más allá del hecho de compartir un hogar y una economía"; agrega que si se interpreta el artículo 97 del Código Civil como manifestación de un Principio General del Derecho, aplicable en defecto de ley o costumbre a relaciones no matrimoniales, "sólo tendría derecho a percibir una compensación aquel que se hubiera empobrecido, generando un enriquecimiento para el otro, resultando, además, perjudicado por la ruptura de la unión, matrimonial o no. De esta forma, tan sólo se desincentivaría la ruptura oportunista de uniones, por decisión del que se ha enriquecido a costa del otro, cuando ya nada tiene que perder por romper, mientras que es el que se ha empobrecido el que sí resulta perjudicado por esa ruptura”, pero
} 
Sin embargo, esta nueva orientación fue nuevamente abandonada mediante la sentencia del Tribunal Supremo de 12 de septiembre de 2005, oportunidad donde acogiéndose el recurso de casación, se revocó la indemnización concedida a la mujer, declarándose en su fundamento de derecho tercero, que "es preciso proclamar que la unión de hecho es una institución que no tiene nada que ver con el matrimonio, aunque las dos estén dentro del derecho de familia. Es más, hoy por hoy, con la existencia juridica del matrimonio homosexual y el divorcio unilateral, se puede proclamar que la unión de hecho está formada por personas que no quieren, en absoluto, contraer matrimonio con sus consecuencias. Por ello debe huirse de la aplicación por 'analogía legis' de normas propias del matrimonio como son los artículos 97, 96 y 98 del Código Civil, ya que tal aplicación comporta inevitablemente una penalización de la libre ruptura de la pareja, y más especialmente una penalización al miembro de la unión que no desea su continuidad. Apenas cabe imaginar nada más paradójico que imponer una compensación económica por la ruptura a quien precisamente nunca quiso acogerse al régimen jurídico que prevé dicha compensación para el caso de ruptura del matrimonio por separación o divorcio"72.

siempre con el límite de no tener que pagar más que aquello a lo que ascienda a ese enriquecimiento, para no obstaculizar la libre ruptura de estas uniones.

Sin embargo, el mismo GAVIDIA SÁnCHEZ (2002), p. 46, reconoce que la realidad del artículo 97 del Código Civil está muy lejos de comprender un Principio General del Derecho, al decir "para mí está claro que las normas contenidas en los artículos 97 y 1438 del Código Civil no son manifestación de un Principio General de Derecho, consistente en la obligación de compensar enriquecimientos sin causa en las relaciones entre quienes mantienen una comunidad de vida, esto es, de cuidados y responsabilidades recíprocos que vaya más allá del hecho de compartir un hogar y unos gastos y tareas domésticos", añadiendo que "en el artículo 97 del Código Civil no es decisivo para tener derecho a la pensión compensatoria que el obligado a prestarla se haya enriquecido a costa del otro, sino que basta con que la separación o el divorcio haya generado una situación de desequilibrio, de manera que uno haya quedado peor que el otro y peor de lo que estaba antes de la crisis conyugal. Se trata, por lo tanto, de normas que favorecen a los casados, respecto a los que mantienen comunidades de vida no matrimoniales. Y, una vez más, la libre ruptura de estas uniones, frente a su exclusión en los matrimonios, justifica la diferencia de trato e impide apreciar identidad de razón, de manera que no son aplicables analógicamente a las uniones no matrimoniales".

${ }^{72}$ En definitiva, determinó recurrir a objeto de solucionar el problema causado con ocasión de la disolución de hecho, a la figura del enriquecimiento sin causa.

No obstante, no podemos dejar de mencionar que en el fallo en referencia existen dos votos particulares: uno, del magistrado O'Callaghan Muñoz, quien era partidario de aplicar el principio general de protección al conviviente más perjudicado, desestimando el recurso de casación, manteniendo la indemnización concedida a la mujer en primera instancia; y dos, de los magistrados Ferrándiz Gabriel y Roca I Trías, quienes compartiendo el fallo de instancia, discreparon de sus argumentos, al sostener "que debería considerarse que, en ciertos casos, pueden aplicarse reglas relativas a los efectos de la ruptura matrimonial y más concretamente las que regulan el derecho a una pensión compensatoria, sin necesidad de utilizar las reglas del enriquecimiento injustificado, que no siempre serán el remedio más adecuado para solucionar el problema planteado". Estos últimos (Ferrándiz y Roca), justifican su opinión señalando que "la aplicación de una regla prevista para las consecuencias de la ruptura matrimonial, como es la pensión compensatoria, no significa necesariamente aplicar analógicamente las reglas del matrimonio, ni tampoco las del enriquecimiento injustificado. Existen tres razones para llegar a esta conclusión: a) Que sólo se contempla la ruptura del matrimonio o la disolución de la unión de hecho. b) Que existe una semejanza evidente entre la ruptura del matrimonio y la disolución de la unión de hecho, aunque hay una diferencia esencial: la falta de régimen económico en estas situaciones no formales, que sin embargo, puede semejarse al caso que se haya pactado un régimen de separación de bienes. c) Que la 
En fin, la misma doctrina que niega la aplicación analógica de los regímenes matrimoniales en general, rechaza la aplicación analógica del artículo 97 del Código Civil apoyada en la vigente jurisprudencia, amparada en los mismos fundamentos expuestos, al sostener que los convivientes por su propia decisión y voluntad han querido huir de los efectos del matrimonio, y en su caso, de la aplicación de la norma en comento, sumado al innegable argumento manifestado por el Tribunal Constitucional en la sentencia de 15 noviembre de 1990, que declaró que ante el Derecho, unión de hecho y matrimonio son dos figuras distintas, donde no existe identidad de razón que permita la aplicación de las normas de una a la otra.

Agregan que el mismo tenor literal del precepto corrobora esta posición, al establecer como supuestos en que opera este derecho el de "separación o divorcio", los cuales sólo pueden acontecer dentro del matrimonio; a igual conclusión lleva la expresión "cónyuge" empleada por el legislador, limitando el campo de aplicación de esta pensión. En el mismo sentido, añaden, si en el caso del matrimonio nulo, que ha tenido apariencia de tal, el legislador no ha concedido el derecho a la pensión compensatoria, menos se justifica concederlo en el supuesto de una convivencia more uxorio.

\subsubsection{Aplicación analógica de la compensación prevista en el artículo $1438^{73}$ del Código Civil}

Esta posición es principalmente defendida por LACRUZ ${ }^{74}$, quien concede un derecho de compensación al conviviente que preste servicios, labores, en forma exclusiva para el hogar ${ }^{75}$. Dicho autor hace aplicable a maiore la norma del artículo

compensación, independientemente del enriquecimiento injustificado, está ya contemplada en otros supuestos, además del artículo 97 del Código Civil, el artículo 98 del Código Civil que aplica el mismo principio de compensación en la nulidad del matrimonio, es decir, cuando no ha habido relación matrimonial por concurrir causa de nulidad, y el artículo 1438 del Código Civil cuando existe régimen de separación de bienes, es decir, falta de comunidad o lo que es lo mismo, lo más parecido a la falta de régimen"; concluyen que "en todos los casos regulados en las disposiciones citadas hay tres elementos que existen también en las situaciones de uniones de hecho y que son: a) la cesación de la convivencia; b) el posible perjuicio que esta cesación produce en una de las partes de la relación, ya sea matrimonial o no matrimonial, y c) la comparación de la situación resultante con la existente durante el matrimonio o la convivencia de hecho. Sólo cuando se den estas circunstancias podrá acordarse la compensación"; por último, añaden que "estos requerimientos no deben confundirse con los que esta Sala ha exigido reiteradamente como requisitos del enriquecimiento injustificado", ya que si bien, no niegan que "puedan existir casos en los que la convivencia haya producido un enriquecimiento que pueda calificarse de injustificado", ello no justifica confundir los dos institutos.

${ }^{73}$ Artículo 1438 CC: "Los cónyuges contribuirán al sostenimiento de las cargas del matrimonio. A falta de convenio lo harán proporcionalmente a sus respectivos recursos económicos. El trabajo para la casa será computado como contribución a las cargas y dará derecho a obtener una compensación económica que el Juez señalará, a falta de acuerdo, a la extinción del régimen de separación".

${ }^{74}$ Lacruz Berdejo, José Luis et al. (1989). Elementos de Derecho Civil IV. Derecho de familia. Vol. II, Barcelona: José María Bosch Editor S.A., 3a Edición actualizada, p. 20.

${ }^{75}$ La norma del artículo 1438 del Código Civil exige para su aplicación, que los servicios se hayan prestado, por una de las partes, al interior del hogar, al hablar de "trabajo para la casa", limitando con ello, el tipo de servicios que puede dar origen a la compensación. 
1438, para el caso de que uno de los convivientes se dedique en forma exclusiva al trabajo de la casa, excluyendo el empleo de otros preceptos del régimen matrimonial a esta convivencia more uxorio ${ }^{76}$.

El fundamento de su posición se encuentra en que cualquier tipo de prestaciones o servicios realizados por uno de los convivientes en beneficio del otro, se deben presumir onerosos, manifestando que "la equidad requiere que las aportaciones de cada conviviente al hogar y la vida en común e incluso el trabajo del otro tengan una consideración onerosa, sin distinguir entre el trabajo del hogar y las prestaciones profesionales o industriales".

Al existir un precepto como el objeto de comentario, que dispone en su fracción pertinente que "el trabajo para la casa será computado como contribución a las cargas y dará derecho a obtener una compensación que el Juez señalará, a falta de acuerdo, a la extinción del régimen de separación", aplicable al matrimonio, no se observa justificación que impida su aplicación a las uniones de hecho, por cuanto los servicios prestados son los mismos, "el trabajo para el hogar", ya lo preste un cónyuge o un conviviente.

A favor de esta posición, podemos recordar que en la unión de hecho no existen efectos personales, con lo cual, no existe un deber de ayuda y socorro mutuo que obligue jurídicamente a prestar este tipo de servicios a uno de sus miembros, y que justifique o ampare su gratuidad; es más, sino se presume la gratuidad de la prestación de esta clase de servicios en el matrimonio, donde existe el deber jurídico que obliga a los cónyuges a cumplirlos, y dentro de los cuales cabe comprender el trabajo para la casa, menos podría presumirse dicha gratuidad en la convivencia more uxorio.

Sin embargo, esta posición es igualmente rechazada por la doctrina dominante, como por la jurisprudencia ${ }^{77}$, amparados en los mismos razonamientos que hacen inaplicable por analogía las normas de los regímenes matrimoniales, y a los cuales

\footnotetext{
${ }^{76}$ En el mismo sentido se expresa Joaquín RAms AlbESA, al revisar y poner al día la obra de LACRUz Berdejo et al. (2008), pp. 293 y ss., pero se limita a manifestar sobre esta cuestión, que "no veo excesivos inconvenientes en la generalización de las reglas sobre levantamiento de cargas familiares por la vía analógica del artículo 1438 del Código Civil", añadiendo, al referirse a la recuperación de las prestaciones realizadas por un conviviente en beneficio del otro relativas a las faenas del hogar, que "en mi opinión, cuando la situación es típicamente familiar, la cooperación de los convivientes puede traducirse, como he apuntado, por la vía de la aplicación analógica del artículo 1438 del Código Civil”.

${ }^{77}$ Véase la sentencia del Tribunal Supremo, de 24 de noviembre de 1994, que resolvió que "en cuanto denuncia la aplicación del artículo 1438, debe partirse de la jurisprudencia reiterada y constante de esta Sala en materia de uniones de hecho, según la cual (sentencias del Tribunal Supremo, de 21 octubre 1992, 11 diciembre 1992, 18 febrero 1993 y 27 mayo 1994) no es posible aplicar a las uniones "more uxorio", las normas reguladoras del régimen legal de la sociedad de gananciales, pues aun reconociéndose la libertad para crear aquellas uniones libres, no pueden ser equiparables al matrimonio, ni pueden serles aplicables sus normas reguladoras (sentencia del Tribunal Constitucional, de 15 noviembre 1990)"; sentencia Audiencia Provincial de Madrid, de 27 de enero de 1997.
} 
nos remitimos. Particular relevancia merece la opinión de ESTRADA AlONSO ${ }^{78}$, que si bien rechaza la aplicación del artículo 1438 del Código Civil, sí comparte la opinión de LACRUZ, en el sentido que las prestaciones y servicios para el hogar realizados por "la conviviente" deben tener naturaleza onerosa, debiendo ser remunerados.

\subsection{Aplicación del principio general de probibición de enriquecimiento sin causa}

Rechazada la interpretación analógica de las normas de los regímenes matrimoniales, la doctrina y actual jurisprudencia sostienen la aplicación del principio de prohibición de enriquecimiento injustificado o sin causa, como el camino idóneo para indemnizar el enriquecimiento patrimonial de uno de los convivientes en perjuicio del otro, toda vez que, existiendo relación de causalidad entre ambos hechos, la unión libre no constituye causa justificada que ampare tal situación ${ }^{79}$.

Si bien, según hemos expuesto en los capítulos anteriores, la acción en comento no tiene un reconocimiento expreso en la legislación civil española actual, sus fundamentos han sido recogidos por la doctrina y jurisprudencia, quienes destacando el principio de equidad, defienden su vigencia.

Es más, en virtud del principio general de prohibición de enriquecimiento sin causa, las Leyes autonómicas y forales, de Cataluña (Ley No 10/1998, de uniones estables de parej ${ }^{80}$ ), de Aragón (Ley No 6/1999, de parejas estables no casadas ${ }^{81}$ ), y de Navarra (Ley Foral 6/2000, de igualdad jurídica de las parejas estables ${ }^{82}$ ), expresamente establecen un derecho a compensación a la disolución de la unión de

\footnotetext{
${ }^{78}$ Estrada Alonso (1991), p. 218.

${ }^{79}$ Véase a Gavidia Sánchez (2003b); Estrada Alonso (1991), pp. 220 y ss.; Jordano Barea (1999), pp. 181 y ss.; Torres García (2000), p. 49; Cerda Gimeno (1993), pp. 586 y ss.; Mesa Marrero (2006), pp. 221 y ss.; De Verda y BeAmonte (2006), pp. 244 y ss.; entre otros.

En cuanto a la jurisprudencia, la sentencia del Tribunal Supremo de 12 de septiembre de 2005, junto con descartar la aplicación del artículo 97 del Código Civil, recurrió “al Principio General del Derecho -artículo 1-1 del Código Civil-y a la figura del enriquecimiento injusto recogida en el artículo 10-9 y en el artículo 1887, ambos de dicho Código, que siempre servirá como "cláusula de cierre» para resolver la cuestión"; véase sentencia del Tribunal Supremo, de 22 de febrero de 2006; entre otras.

${ }^{80}$ Artículo 13: "Cuando la convivencia cesa en vida de los dos convivientes, aquel que, sin retribución o con retribución insuficiente, haya trabajado para el hogar común o para el otro conviviente, tiene derecho a recibir una compensación económica en caso de que se haya generado por este motivo una situación de desigualdad entre el patrimonio de los dos que implique un enriquecimiento injusto".

${ }^{81}$ Artículo 7: "1.- En caso de extinción de la pareja estable no casada por causa distinta a la muerte o declaración de fallecimiento, y si la convivencia ha supuesto una situación de desigualdad patrimonial entre ambos convivientes que implique un enriquecimiento injusto, podrá exigirse una compensación económica por el conviviente perjudicado en los siguientes casos: a) Cuando el conviviente ha contribuido económicamente o con su trabajo a la adquisición, conservación o mejora de cualquiera de los bienes comunes o privativos del otro miembro de la pareja estable no casada; b) Cuando el conviviente, sin retribución o con retribución insuficiente, se ha dedicado al hogar, o a los hijos comunes o del otro conviviente, o ha trabajado para éste".

${ }^{82}$ Artículo 5.5: "En defecto de pacto, cuando la convivencia cesa en vida de los dos convivientes, aquel que, sin retribución o con retribución insuficiente, haya trabajado para el hogar común o para el otro conviviente, tiene
} 
hecho, evitando de esa forma situaciones de enriquecimiento injusto que podrían darse a raíz de la vigencia de la convivencia.

Ahora, sobre su aplicación a las uniones de hecho, primero la doctrina, y segundo la jurisprudencia, la admiten plenamente en el caso de cumplirse los requisitos necesarios para ella, a recordar, enriquecimiento patrimonial de uno de los convivientes, empobrecimiento correlativo del actor, relación de causalidad entre uno y otro, es decir, que el empobrecimiento de uno sea la causa determinante del enriquecimiento del otro, y falta de causa que la justifique.

Concretando éstos, el hecho que uno de los convivientes haya prestado gratuitamente servicios al otro, ya sean de índole doméstico, como el cuidado de los hijos, o el trabajo de la casa, o hubiera colaborado en las actividades profesionales o laborales, produce en el conviviente beneficiado con dichos servicios, un enriquecimiento en su patrimonio, en forma positiva, incrementándolo, o negativa, evitándose un gasto, el cual, correlativamente ha causado en la otra parte una disminución patrimonial, al no percibir ninguna o la equitativa contraprestación por el trabajo realizado.

Así se aprecia en la sentencia del Tribunal Supremo, de 17 de junio de 2003, donde se declaró que "las circunstancias específicas del supuesto de autos revelan que doña Josefa $C$. durante los cincuenta y tres años de convivencia con don José María $C$. se dedicó en exclusiva a la atención del mismo y del hogar familiar prestándole total ayuda moral y material, lo que repercutió positiva y significativamente en la formación del patrimonio de aquél, al tiempo que acarreó un desentendimiento de su propio patrimonio, pues tal dedicación no sólo no le supuso ninguna retribución o compensación económica, sino que le impidió obtener beneficios privativos mediante el desarrollo de otra actividad en provecho propio... No cabe negar que de la composición fáctica expresada se desprenda una situación de enriquecimiento injusto. Esta situación tiene lugar cuando se ha producido un resultado por virtud del cual una persona se enriquece a expensas de otra que, correlativamente, se empobrece careciendo de justificación o de causa (base) que lo legitime, de tal manera que surge una obligación cuya prestación tiende a eliminar el beneficio del enriquecimiento indebido ('in quantum locupletiores sunt'). El enriquecimiento, como ya advierte la mejor doctrina, se produce, no sólo cuando hay un aumento del patrimonio, o la recepción de un desplazamiento patrimonial, sino también por una no disminución del patrimonio ('damnum cessans'). El empobrecimiento no tiene por qué consistir siempre en el desprendimiento de valores patrimoniales, pues lo puede constituir la pérdida de expectativas y el abandono de la actividad en beneficio propio por la dedicación en beneficio de otro. La correlación entre ambos es la medida en que uno determina el otro, y la falta de causa no es otra cosa que la carencia de razón jurídica que fundamente la situación. La causa (en el sentido de 'razón'o 'base' suficiente) no es, desde el punto de vista jurídico, otra cosa-como

derecho a recibir una compensación económica en caso de que se haya generado por este motivo una situación de desigualdad entre el patrimonio de ambos que implique un enriquecimiento injusto". 
sostiene un importante sector doctrinal-que un concepto-válvula para poder introducir elementos de carácter valorativo, y decidir de tal manera acerca de la justificación, o falta de la misma, en un supuesto determinado... La comunidad de vida, o el haber gozado de una consideración social y material equiparada a la de su compañero (a que se hace referencia en la resolución de la instancia), no constituyen justificación del desequilibrio patrimonial producido en virtud de las respectivas actividades y circunstancias especificas del caso, sumamente significativas. Bueno es apuntar finalmente que se está haciendo referencia a un enriquecimiento producido en el patrimonio del señor C., que genera una obligación resarcitoria ya nacida en vida del mismo, y en absoluto compensada. No se hace referencia a ningún derecho sucesorio, ni se toma en cuenta el enriquecimiento de la demandada" ${ }^{83}$.

Según Estrada Alonso ${ }^{84}$, en estos supuestos, la falta de causa se demuestra en la ausencia de un negocio jurídico válido y eficaz, como en la inexistencia de una expresa disposición legal que autorice aquella consecuencia. Por su parte, GAVIDIA SÁNCHEZ ${ }^{85}$, entiende que para dar por acreditado el requisito de la falta de causa que justifique esta acción, se puede invocar el principio general de protección del conviviente perjudicado por la situación de hecho ${ }^{86}$, empleándolo como una herramienta eficaz para despejar los obstáculos que ésta pudiera plantear ${ }^{87}$.

En todo caso, es menester destacar que tanto el empobrecimiento como el enriquecimiento deben haberse producido durante la vigencia de la unión de hecho, no a raíz de su disolución. Ello es muy significativo, porque nos permite concluir que, el conviviente menoscabado en su patrimonio no tendrá que

\footnotetext{
${ }^{83}$ En el mismo sentido, véase la sentencia del Tribunal Supremo, de 6 de octubre de 2006, que desestimando el recurso de casación, confirmó el fallo de segunda instancia que condenó al demandado a pagarle a la actora la cantidad que se fijará en ejecución de sentencia, por el enriquecimiento injusto merced a los servicios a él prestados por aquélla durante los años de convivencia comprendidos entre agosto de 1987 y febrero de 1993; entre otras.

${ }^{84}$ Estrada Alonso (1991), p. 225.

${ }^{85}$ GAVidia SÁNCHEZ (2003b).

${ }^{86}$ Este principio ha sido reconocido por la jurisprudencia del Tribunal Supremo, como se aprecia en la sentencia de 10 de marzo de 1998, declarando que "deriva de normas constitucionales (artículo 10, principio de dignidad de la persona, artículo 14, principio de igualdad, artículo 39, principio de protección a la familia), de normas de Derecho privado, como el Código Civil (el propio artículo 96) y la Ley No 29/1994, de 24 noviembre (RCL 19943272 y RCL 1995\1141), de Arrendamientos Urbanos [cuyo artículo 16.1, b), entre otros, reconoce expresamente la protección al conviviente], de las sentencias del Tribunal Constitucional (todas las citadas anteriormente) y de las mismas sentencias de esta Sala, en las que prácticamente todas ellas reconocen derechos al conviviente perjudicado"; también pueden verse la sentencia del Tribunal Supremo, de 5 de febrero de 2004; sentencia de la Audiencia Provincial de Vizcaya, de 11 de diciembre de 1998; sentencia del Juzgado de Primera Instancia No 1 de Santander (Provincia de Cantabria), de 7 de febrero de 2005; entre otras.

${ }^{87}$ No obstante, el mismo GaVidia SÁnchez (2003a), p. 131, y en GaVIdia SÁncheZ (2002), p. 40, al comentar la sentencia del Tribunal Supremo, de 11 de diciembre de 1992, plantea dudas respecto de que por el solo hecho de no existir una obligación que vincule a los convivientes a realizarse prestaciones, éstas carezcan de justificación, ya que cuando se trata de prestaciones realizadas para crear y mantener la comunidad de vida, "sería justa causa el mantenimiento de una comunidad de vida, como la que constituye una unión libre (arg. artículo $1901 \mathrm{CC}$, 'otra justa causa')”.
} 
esperar a la ruptura para el ejercicio de la acción, reafirmando la regla general, en orden a que la disolución no es fuente de daño, lícito o ilícito; la finalización de la unión libre sólo sirve para evidenciar el enriquecimiento y el correlativo empobrecimiento, el cual no se hacía patente por las normales relaciones de la convivencia more uxorio.

Según De Verda ${ }^{88}$, del examen de la jurisprudencia del Tribunal Supremo ${ }^{89}$, se puede concluir que los supuestos en que se ha admitido la aplicación de este principio, generalmente ha "existido una larga convivencia more uxorio con dedicación exclusiva de la mujer a las tareas domésticas", donde la ruptura de la unión puede ser motivada por la decisión unilateral del hombre o su muerte, ya que el objetivo que se pretende es "compensar económicamente al conviviente perjudicado por el enriquecimiento sin causa de su compañero", pero no sancionarlo por la disolución de la misma. Así se observa en la sentencia de la Audiencia Provincial de Valencia (Sección 9), de 21 de octubre de 2002, al resolver que "este Tribunal entiende que la actora debe percibir una compensación económica de la herencia del señor M., por razón del empobrecimiento que ha significado la dedicación de veinte años de su vida a ser ama de casa con el señor M., facilitando a éste de este modo la dedicación exclusivamente a pintar y conseguir la comercialización de sus cuadros".

Idénticamente a lo sostenido a lo largo de este trabajo, esta acción sólo puede tener por finalidad indemnizar el empobrecimiento patrimonial padecido por el conviviente, aunque el enriquecimiento sea superior al empobrecimiento; ahora, si el enriquecimiento es menor al empobrecimiento, el actor sólo podrá ser resarcido hasta el tope del primero, aunque el segundo lo exceda.

Si bien, reconocemos que la acción de enriquecimiento es una acción subsidiaria, advertimos que frente a la anomia, no encontramos otra vía más adecuada que ésta; descartada la aplicación analógica de las normas relativas a la liquidación de los regímenes matrimoniales, como la compensación económica prevista en el artículo 97, como la compensación del artículo 1438 del Código Civil, sostenemos que el principio de prohibición del enriquecimiento sin causa debe ser estimado como principal para el restablecimiento del desequilibrio patrimonial ocasionado bajo este escenario.

Para culminar este punto, creemos que lo más oportuno es hacerlo citando un fragmento de la sentencia del Tribunal Supremo, de 11 de diciembre de 1992, que fue pionera en acoger esta orientación, al decir en su considerando cuarto que "no se halla justificado el enriquecimiento del demandado, al menos en la parte apreciada por el Tribunal a quo, porque el ordenamiento jurídico no determina que la convivencia extramatrimonial constituya a quienes optan por ella en la obligación de prestarse determinadas atenciones -en sus relaciones profesionales o sociales, vida

${ }^{88}$ De Verda y Beamonte (2006), pp. 245 y ss.

${ }^{89}$ Se apoya en las sentencias del Tribunal Supremo, de 11 de diciembre de 1992; de 27 de marzo de 2001; de 17 de enero de 2003, y de 17 de junio de 2003. 
doméstica, etc.- en la forma que está probado lo vino realizando la señora $M$. Es evidente, por último, que no existe precepto legal que excluya, para este caso, la consecuencia indemnizatoria adecuada al enriquecimiento sin causa".

\section{CONCLUSiOnes}

La revisión efectuada nos ha permitido conocer cuáles son las diversas soluciones que la doctrina y jurisprudencia española han adoptado para dar solución a la situación patrimonial de las uniones de hecho, los requisitos, fundamentos, y críticas en cada caso, distinguiendo para ello distintos escenarios posibles, a saber: a) que los convivientes mediante pacto expreso las hayan estipulado; b) que éstas se deduzcan de hechos o circunstancias que demuestren su voluntad tácita de sujetarse a una figura en particular, como pueden ser la constitución de una sociedad irregular universal o particular de bienes, o la existencia de una comunidad de bienes, o de una relación laboral; c) la aplicación de las normas sobre liquidación de los regímenes económicos matrimoniales, como puede ser la pensión compensatoria o la compensación prevista en el artículo 1438 del Código Civil, y d) la aplicación del principio general de prohibición de enriquecimiento sin causa.

En el caso particular, de la aplicación de la pensión compensatoria como herramienta para solucionar la situación patrimonial de las uniones de hecho, vemos que la sentencia de 7 de marzo de 2012, de la Corte Suprema chilena que rechazó los recursos de casación y validó la sentencia dictada por la Corte de Apelaciones de Valparaíso, de 4 de noviembre de 2010, y que reconoció el derecho a una conviviente a percibir una compensación económica, no resulta novedosa en comparación a la jurisprudencia española, ya que el Tribunal Supremo, con fecha 5 de julio de 2001, se pronunció en similar sentido, aplicando por analogía legis esta compensación a las uniones de hecho. No obstante lo anterior, debemos recalcar que en la jurisprudencia española actual, después de las reformas del año 2005 que han consagrado el matrimonio homosexual y el divorcio unilateral, se ha producido un cambio de posición frente a esta cuestión, ya que ahora se rechaza la aplicación de la compensación económica a las uniones de hecho, toda vez que se entiende que ésta está formada por personas que no quieren, en absoluto, contraer matrimonio con sus consecuencias; que no hay nada más paradójico que imponer una compensación económica por la ruptura a quien precisamente nunca quiso acogerse al régimen jurídico que consagra dicha compensación.

De las diversas soluciones planteadas, en la actualidad, la doctrina y jurisprudencia española se inclinan por la aplicación del principio general de prohibición de enriquecimiento sin causa, como la herramienta para indemnizar, reembolsar, el enriquecimiento patrimonial de uno de los convivientes en perjuicio del otro, fundándose para ello en el principio de equidad. 


\section{BiBLIOGRAFÍA CITADA}

Cerda Gimeno, José (1993). "La situación actual de las parejas no casadas ante el Derecho". En: Estudios sobre Derecho de Familia, Colegio de Registradores de la Propiedad y Mercantiles de España, Centro de Estudios Registrales, Madrid: Ed. San José.

De la Haza Díaz, Pilar (1989). La pensión de separación y divorcio. Madrid: La Ley.

De Verda y Beamonte, José Ramón (2006). "Efectos económicos de la ruptura de uniones de hecho". En: Daños en el Derecho de Familia, De Verda y Beamonte, José Ramón (Coord.), Revista de Derecho Patrimonial, No 17, Monografía Asociada a Revista Aranzadi de Derecho Patrimonial, Navarra: Editorial Thomson-Aranzadi.

DíEz-PICAzo, Luis (1996). Fundamentos del derecho civil patrimonial. Vol. 1, Introducción, Teoría del Contrato, Madrid: Editorial Civitas, 5ª Edición.

Díez-PicAzo, Luis y Gullón, Antonio (2006). Sistema de Derecho Civil. Vol. IV, Derecho de familia. Derecho de sucesiones, Madrid: Editorial Tecnos, 10a Edición.

Estrada Alonso, Eduardo (1991). Las Uniones Extramatrimoniales en el Derecho Civil Español. Madrid: Editorial Civitas, 2a Edición.

Ferrer Ortiz, Javier (1997). "Familia y Derecho". En: XV Jornadas de la Asociación Española de Canonistas en el XXV Aniversario de su fundación, Madrid 19-21 de abril de 1995, Salamanca: Publicaciones Universidad Pontificia de Salamanca.

Fosar Benlloch, Enrique (1983). "Análisis de la Jurisprudencia española sobre las relaciones económicas en las uniones extramatrimoniales". Revista General de Legislación y Jurisprudencia, No 3, marzo.

García-Posada GÓMEZ, Elda (2003). "El concepto de convivencia no matrimonial en Derecho español”. En: $A D C$, T. LVI, fascículo III, julio-septiembre.

GAVIDIA SÁNCHEZ, Julio Vicente (2002). "Analogía entre el matrimonio y la unión libre en la jurisprudencia del Tribunal Supremo y principio de libre ruptura de las uniones no matrimoniales". En: Aranzadi Civil, núm. 6/2002 (Estudio), Pamplona: Editorial Aranzadi S.A. (BIB 2002/655).

Gavidia SÁnchez, Julio Vicente (2003a). "Comentario a la sentencia de 16 de julio de 2002”. En: Cuadernos Civitas de Jurisprudencia Civil, No 61, enero-abril.

Gavidia Sánchez, Julio Vicente (2003b). "Pactos entre convivientes, enriquecimiento injusto y libre ruptura de las uniones no matrimoniales". Diario La Ley, No $5861,1^{\circ}$ de octubre.

Gitrama GonzÁlez, Manuel (1984). "Notas sobre la problemática jurídica de la pareja no casada". En: Estudio de Derecho Civil en Homenaje al profesor J. Beltrán de Heredia y Castaño, Salamanca: Ediciones Universidad de Salamanca. 
Jordano Barea, Juan (1999). "Matrimonio y unión libre". En: Actualidad Civil, No IX.

Lacruz Berdejo, José Luis et al. (1989). Elementos de Derecho Civil IV. Derecho de familia. Vol. II, Barcelona: José María Bosch Editor S.A., 3a Edición actualizada.

Lacruz Berdejo, José Luis et al. (2008). Elementos de Derecho Civil IV. Derecho de familia. Madrid: Editorial Dykinson, 3a Edición revisada y puesta al día por Joaquín Rams Albesa.

LÓPEZ JimÉnEZ, David (2006). "La aplicación analógica de la pensión compensatoria como criterio de resolución de las reclamaciones económicas entre los convivientes". En: Aranzadi Civil, núm. 16/2006 (Estudio), Pamplona: Editorial Aranzadi S.A. (BIB 2006/1685).

Martínez-Calcerrada, Luis (1981). "La familia en la Constitución española". Revista de Derecho Privado, noviembre.

Mesa Marrero, Carolina (2006). Las uniones de hecho, Análisis de las relaciones económicas y sus efectos. Navarra: Thomson-Aranzadi, $3^{a}$ Edición actualizada y aumentada.

Noir-Masnata, Catherine (1986). Los efectos patrimoniales del concubinato y su influencia en el deber de sostenimiento entre esposos separados. CAMPOS Cово, Juan de Dios (Trad.), Madrid: Editorial Revista de Derecho Privado.

Orcaray Reviriego, Javier (2002). "Convivencia 'more uxorio'. A propósito de la sentencia del Tribunal Supremo de 24 febrero 2000, que otorga el derecho a la prestación por desempleo a trabajadora despedida por el empresario con el que convive”. En Boletín Aranzadi Laboral, núm. 7/2002 (parte Boletín), Pamplona: Editorial Aranzadi (BIB 2002/1261).

Pantaléon Prieto, Fernando (1986). "La autorregulación de la unión libre". Revista del Poder Judicial, No 4, diciembre.

Pérez Vallejo, Ana María (1999). Autorregulación en la convivencia de hecho (a propósito de las recientes disposiciones prelegislativas y legislativas tendencialmente más dispositivas). Universidad de Almería, Almería: Servicio de Publicaciones.

Puga Gómez, Santos (2003) "La convivencia more uxorio y la sentencia del Tribunal Supremo de fecha 17 de enero de 2003". En: Boletín Aranzadi CivilMercantil, núm. 49/2002 (Boletín), Pamplona: Editorial Aranzadi S.A. (BIB 2003/428).

Reina, Víctor y Martinell, Josep (1995). Curso de derecho matrimonial. Madrid: Marcial Pons.

Reina, Víctor y Martinell, Josep (1996). Las uniones matrimoniales de hecho. Madrid: Marcial Pons.

Rivero Hernández, Francisco (1998). "Comentario a la sentencia de 29 de octubre de 1997”. En: Cuadernos Civitas de Jurisprudencia Civil, T. 46, enero-marzo. 
Rodríguez Guitián, Alma María (2003). "Función de la responsabilidad civil en determinadas relaciones de convivencia: daños entre cónyuges y daños entre los miembros de la pareja de hecho". En: Revista de Derecho Patrimonial, No 10, Pamplona: Editorial Aranzadi.

Torres García, Teodora (2000). "Régimen económico matrimonial y uniones de hecho". En: Matrimonio y Uniones de Hecho, Martínez Gallego, Eva María (Coord.), Salamanca: Ediciones Universidad de Salamanca, $1^{\text {a }}$ Edición. 